\title{
A20 at the Crossroads of Cell Death, Inflammation, and Autoimmunity
}

\author{
Arne Martens ${ }^{1,2}$ and Geert van Loo ${ }^{1,2}$ \\ ${ }^{1}$ VIB Center for Inflammation Research, 9052 Ghent, Belgium \\ ${ }^{2}$ Department of Biomedical Molecular Biology, Ghent University, 9052 Ghent, Belgium \\ Correspondence: geert.vanloo@irc.vib-ugent.be
}

A20 is a potent anti-inflammatory protein, acting by inhibiting nuclear factor $\kappa \mathrm{B}(\mathrm{NF}-\kappa \mathrm{B})$ signaling and inflammatory gene expression and/or by preventing cell death. Mutations in the A20/TNFAIP3 gene have been associated with a plethora of inflammatory and autoimmune pathologies in humans and in mice. Although the anti-inflammatory role of A20 is well accepted, fundamental mechanistic questions regarding its mode of action remain unclear. Here, we review new findings that further clarify the molecular and cellular mechanisms by which A20 controls inflammatory signaling and cell death, and discuss new evidence for its involvement in inflammatory and autoimmune disease development.

nflammation is a protective response to induce repair in conditions of cellular damage and stress. It involves activation of the nuclear factor $\kappa \mathrm{B}(\mathrm{NF}-\kappa \mathrm{B})$ family of transcription factors leading to the expression of inflammatory cytokines and chemokines to establish an appropriate immune response. Activation of NF- $\kappa \mathrm{B}$ also induces the expression of cell-survival genes to protect the cell from dying (Zhang et al. 2017). NF- $\kappa \mathrm{B}$ signaling is tightly regulated at multiple levels and strongly depends on reversible modification of signaling proteins, with important roles for phosphorylation and ubiquitination. Ubiquitination is a posttranslational protein modification in which ubiquitin (Ub), a small 76-amino-acid protein, is covalently attached to lysine residues of target proteins by the stepwise activity of an E1 Ub-activating enzyme, E2 Ub-conjugating enzymes, and E3 Ub protein ligases. Each of the seven lysine residues (K6, K11, K27, K29, K33, K48, and K63) in Ub can themselves be bound to another Ub, leading to the formation of polyubiquitin chains on the target protein. Linear Ub chains (M1), in which $\mathrm{Ub}$ is bound via the amino-terminal methionine (M1) residue to another $\mathrm{Ub}$, also happens, and has been shown to be crucially important for NF- $\kappa \mathrm{B}$ signaling (Iwai and Tokunaga 2009). Depending on the type of chain, ubiquitination can target the modified protein for proteasomal degradation, or function as a scaffold for proteins that contain a Ub-binding domain (UBD) and mediate downstream signaling. Ubiquitination is reversed by deubiquitinating enzymes (DUBs) that cleave Ub chains from their substrate (Hrdinka and Gyrd-Hansen 2017). Hence, the ubiquitination of proteins, defined by the tight interplay between $\mathrm{Ub}$

Editors: Kim Newton, James M. Murphy, and Edward A. Miao

Additional Perspectives on Cell Survival and Cell Death available at www.cshperspectives.org

Copyright (C) 2020 Cold Spring Harbor Laboratory Press; all rights reserved; doi: 10.1101/cshperspect.a036418

Cite this article as Cold Spring Harb Perspect Biol 2020;12:a036418 
ligases, Ub-binding proteins, and DUBs, controls NF- $\mathrm{KB}$ signaling.

The importance of ubiquitination for the regulation of inflammatory signaling has been studied extensively for the prototype inflammatory pathway induced by the cytokine tumor necrosis factor (TNF) (Verhelst et al. 2011). Binding of TNF to its cognate receptor TNF receptor 1 (TNFR1) mediates NF- $\kappa B$-dependent gene activation through assembly of a primary membrane-bound signaling complex known as complex I (Ting and Bertrand 2016). This complex is assembled through the recruitment of TNF receptor-associated death domain protein (TRADD), receptor-interacting protein 1 (RIPK1), TNF receptor-associated factor 2 (TRAF2) and/or TRAF5, and cellular inhibitor of apoptosis protein-1 (cIAP1) and cIAP2. cIAP1 and cIAP2 are E3 Ub ligases that on recruitment conjugate RIPK1 and cIAPs themselves with K63-linked polyubiquitin chains, which now serve as a platform for the recruitment of the linear $\mathrm{Ub}$ chain assembly complex (LUBAC), consisting of HOIP, HOIL1, and SHARPIN. As a consequence, LUBAC will conjugate several components of the TNFR1 complex with M1-linked chains, followed by the recruitment and activation of the TAB-TAK1 complex and the NEMO-IKK complex via their UBD domains (Haas et al. 2009). This allows TAK1 to phosphorylate and activate the IKK complex, the latter phosphorylating the inhibitor of $\kappa B \alpha(\mathrm{I} \kappa \mathrm{B} \alpha)$, targeting it for proteasomal degradation. Degradation of I $\mathrm{K} \alpha$ releases NF$\kappa \mathrm{B}$, which now translocates to the nucleus where it induces the expression of proinflammatory and cell-survival genes (Fig. 1; Zhang et al. 2017). Besides activating NF- $\mathrm{KB}$ and inducing inflammatory gene activation and cell survival, TNF can also induce the assembly of a cytosolic death-inducing signaling complex (DISC) composed of TRADD, Fas-associated death domain (FADD), and caspase-8 (complex IIa), or composed of RIPK1, FADD, and caspase- 8 (complex IIb, also called the Ripoptosome). In conditions of caspase-8 inhibition, TNF can induce necroptosis by further recruitment of RIPK3 and mixed lineage kinase domain-like pseudokinase (MLKL) assembling the ne- crosome (Fig. 1; Pasparakis and Vandenabeele 2015; Ting and Bertrand 2016).

Deregulation of inflammatory NF- $\kappa \mathrm{B}$ and cell-death signaling has been associated with several (auto)inflammatory diseases and cancer (Kondylis et al. 2017; Lork et al. 2017). Therefore, tight regulation of these pathways is required to avoid chronic inflammation and maintain tissue homeostasis. In this context, numerous (auto)regulatory mechanisms have been described (Renner and Schmitz 2009), and A20, CYLD, and OTULIN have been identified as key players in the negative regulation of NF- $\mathrm{KB}$ and cell death in response to TNF (Lork et al. 2017). In this review, we will discuss the molecular mechanisms by which A20 regulates NF- $\mathrm{\kappa B}$ signaling and cell death, its own regulation, and our current knowledge on its involvement in inflammatory and autoimmune pathology.

\section{A20 STRUCTURE AND MECHANISM OF NF-KB REGULATION}

A20, also known as TNF- $\alpha$-induced protein 3 (TNFAIP3), was first discovered as a primary response gene that is expressed on stimulation of human endothelial cells with TNF, protecting the cells from TNF-induced cell death (Dixit et al. 1990). Although A20 was initially characterized as an inhibitor of TNF-induced apoptosis, further studies identified A20 as a negative regulator of TNF-induced NF- $\mathrm{KB}$ activation, but also of NF- $\mathrm{KB}$ signaling downstream from the interleukin 1 receptor (IL-1R), pathogen recognition receptors (PRRs), NOD-like receptors (NLRs), T- and B-cell receptors, and CD40 (Opipari et al. 1990; Catrysse et al. 2014). The basal expression of A20 is low in most cell types, but is rapidly and transiently induced in inflammatory conditions through NF- $\kappa \mathrm{B}$-dependent transcription owing to the presence of two $\mathrm{\kappa B}$ elements in the $A 20$ promotor region (Krikos et al. 1992). A20 thus behaves as a prototype negative feedback regulator of NF- $\kappa B$ signaling.

A20 has been characterized as a so-called "Ub-editing" enzyme that inhibits NF- $\mathrm{KB}$ signaling by interfering with the ubiquitination status of multiple NF- $\kappa \mathrm{B}$ signaling proteins (Wertz et al. 2004). The A20 protein consists 


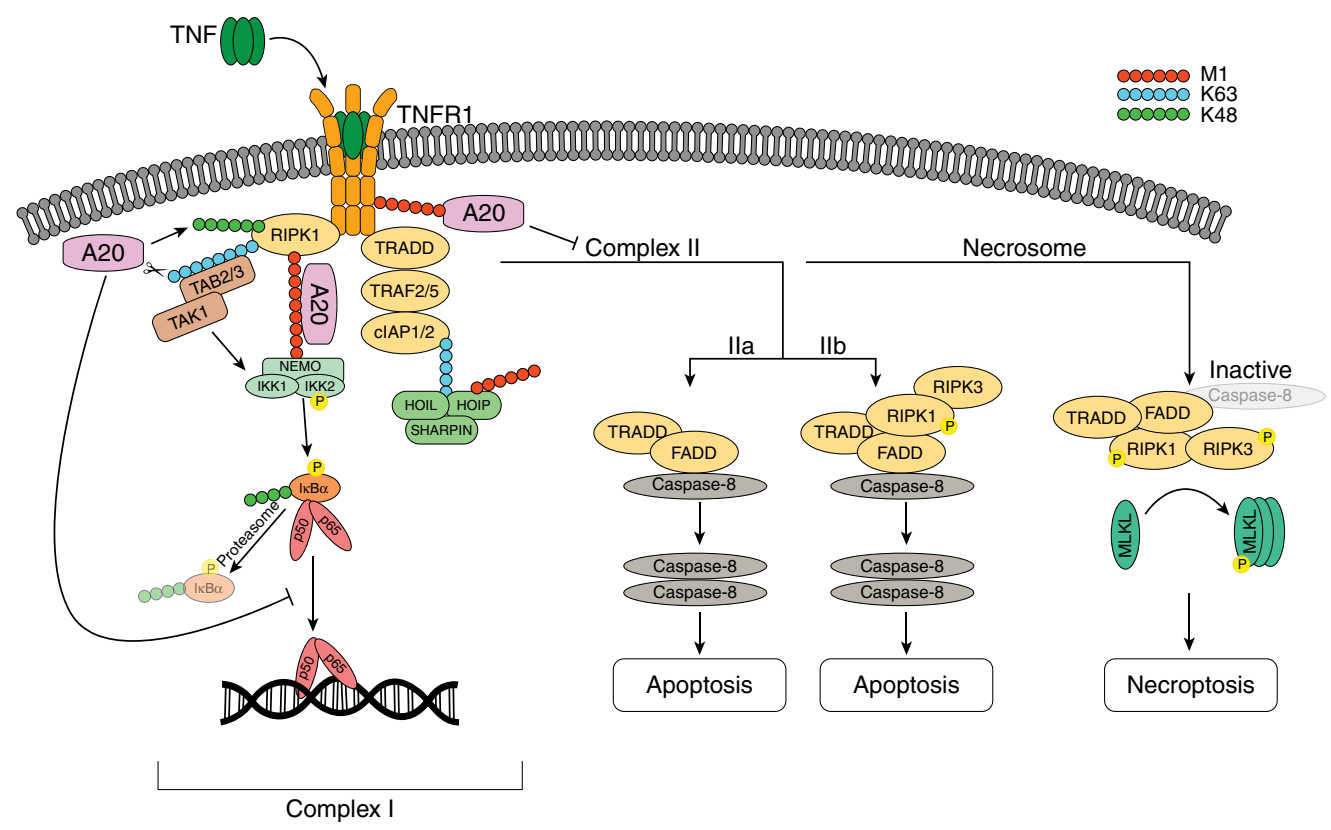

Figure 1. Tumor necrosis factor (TNF)-induced nuclear factor $\kappa \mathrm{B}(\mathrm{NF}-\kappa \mathrm{B})$ signaling, apoptosis, and necroptosis. Binding of TNF to TNF receptor 1 (TNFR1) induces receptor trimerization that allows the recruitment of TNF receptor-associated death domain protein (TRADD) and receptor-interacting protein 1 (RIPK1). TRADD recruits TRAF2/5 and the E3 ubiquitin (Ub) ligases cIAP1 and cIAP2. cIAP1 and cIAP2 conjugate RIPK1 as well as themselves with K63-linked polyubiquitin chains, which serve as a platform for the recruitment of the LUBAC complex, consisting of HOIP, HOIL1, and SHARPIN. Linear Ub chain assembly complex (LUBAC) conjugates several components of the TNFR1 complex, including NEMO and RIPK1, with linear Ub chains (M1). The TAB2/3-TAK1 complex binds K63-linked chains on RIPK1, whereas the IKK complex is recruited via NEMO binding to M1-linked polyubiquitin. This allows TAK1 to phosphorylate and activate the IKK complex. On activation, IKK 2 phosphorylates the inhibitor of $\kappa B \alpha(\mathrm{I} \kappa \mathrm{B} \alpha)$, targeting I $\mathrm{B} \mathrm{B} \alpha$ for ubiquitination with K48linked chains and proteasomal degradation. This releases the p50/p65 NF- $\kappa B$ dimer, which translocates to the nucleus where it induces the expression of NF- $\kappa \mathrm{B}$ response genes. A20 is recruited to the TNFR1 signaling complex via M1-linked Ub, which binds to ZnF7. In addition, A20 has been shown to act as a deubiquitinating enzyme (DUB) that removes K63-linked polyubiquitin from different target proteins, including RIPK1 and NEMO. Furthermore, A20 has been shown to target RIPK1 and TNFR1 for proteasomal degradation through its ZnF4 E3 ligase activity. Binding of A20 to M1-linked polyubiquitin prevents downstream signaling by competing with other Ub-binding proteins and by preventing the degradation of M1-linked chains by CYLD (not shown). Loss of M1-linked chains destabilizes complex I and results in the formation of a cytosolic deathinducing signaling complex (DISC), consisting of TRADD, Fas-associated death domain (FADD), and caspase 8 (complex IIa) or RIPK1, FADD, and caspase-8 (complex IIb). Homodimerization and activation of caspase-8 leads to the activation of downstream executioner caspases 3 and 7 (not shown) and apoptotic cell death. If caspase- 8 activity is compromised, RIPK1 associates with RIPK3 (the necrosome), which is activated by autophosphorylation. The activated necrosome recruits and activates MLKL inducing necroptotic cell death.

of an amino-terminal ovarian tumor (OTU) domain, which has DUB activity, and carboxy-terminal zinc finger $(\mathrm{ZnF})$ domains, with the fourth $\mathrm{ZnF}$ domain shown to have Ub E3 ligase activity (Wertz et al. 2004). In addition, the ZnF4 domain was shown to act as a UBD for K63- linked polyubiquitin (Bosanac et al. 2010). More recently, the seventh $\mathrm{ZnF}(\mathrm{ZnF} 7)$ domain of A20 was shown to function as a UBD, but with high binding affinity for M1-linked Ub (Fig. 2; Tokunaga et al. 2012; Verhelst et al. 2012). The Ub editing function of A20 was first shown in 
A. Martens and G. van Loo

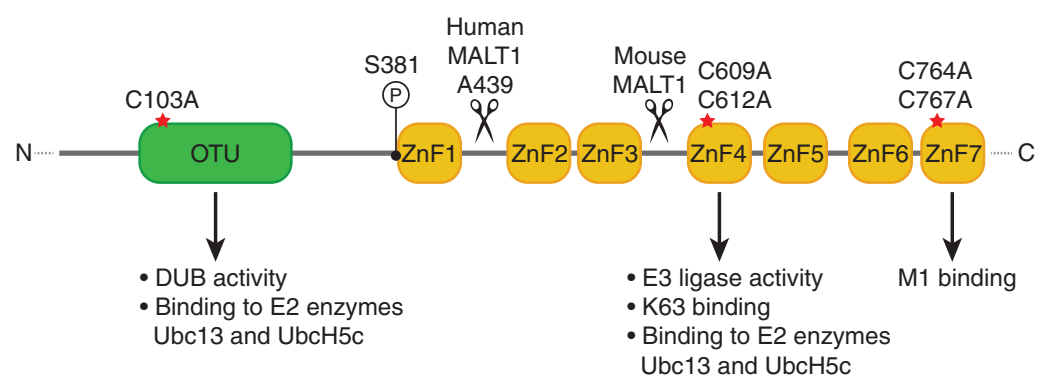

Figure 2. Domain structure of the A20 protein. The amino terminus of A20 contains an ovarian tumor (OTU) domain, which has deubiquitinating enzyme (DUB) activity relying on the catalytic residue Cys103. The carboxy-terminal part of A20 contains seven zinc finger $(\mathrm{ZnF})$ domains. The fourth $\mathrm{ZnF}$ domain has K63-linked polyubiquitin-binding affinity and possesses E3 ubiquitin (Ub) ligase activity, whereas the seventh ZnF domain has strong binding affinity for linear (M1) Ub chains. IKK2-mediated phosphorylation of A20 at Ser381 enhances the DUB activity of A20 toward K63-linked polyubiquitin. MALT1 cleaves A20 at Ala439 in human, or between the third and fourth $\mathrm{ZnF}$ domains in mouse. Mutations that were introduced to generate OTU (C103A), ZnF4 (C609A, C612A), or ZnF7 (C764A, C767A) domain-specific mutant mice are depicted by red stars. Both the OTU and $\mathrm{ZnF} 4$ domains have been shown to bind to E2 enzymes Ubc13 and UbcH5c.

TNFR1 signaling. Using its tandem DUB-E3 ligase activities, A20 was shown to negatively regulate NF- $\kappa \mathrm{B}$ signaling by replacing K63-linked chains on RIPK1 with K48-linked chains, which targeted RIPK1 for proteasomal degradation (Wertz et al. 2004). A20 was also shown to deubiquitinate TNFR1 and NEMO after TNF stimulation (Mauro et al. 2006; Wertz et al. 2015). This DUB activity of A20 was further shown to be promoted by IKK2-mediated phosphorylation of A20 at Ser381 (Fig. 2; Mauro et al. 2006; Wertz et al. 2015).

Besides its role in regulating TNF-induced NF- $\kappa \mathrm{B}$ signaling, the DUB activity of A20 was shown to regulate TLR4- and NOD2-induced NF- $\mathrm{KB}$ activation by removing K63-linked chains from TRAF6 and RIPK2, respectively (Boone et al. 2004; Hitotsumatsu et al. 2008). Furthermore, A20 was shown to negatively regulate T-cell receptor (TCR)-induced NF- $\kappa \mathrm{B}$ activation by deubiquitinating MALT1, thereby preventing the interaction between MALT1 and the IKK complex (Mauro et al. 2006; Duwel et al. 2009). Besides functioning as a DUB, A20 can also affect the ubiquitination of signaling mediators indirectly by interfering with the interaction between E2 and E3 enzymes, limiting polyubiquitin formation. In this context, A20 was shown to disrupt the interaction of TRAF6 with the E2 conjugating enzymes Ubc13 and $\mathrm{UbcH} 5 \mathrm{c}$ in response to IL-1 and LPS stimulation. Similarly, on TNF stimulation, A20 was shown to prevent the association between Ubc13 and both cIAP1 and TRAF2 (Shembade et al. 2010).

Despite many reports claiming a crucial role of $A 20$ as a DUB regulating NF- $\kappa B$ signaling, the physiological relevance of the deubiquitinase activity of A20 is still unclear. Recently, a number of transgenic mouse lines bearing a point mutation in the catalytic OTU domain (A20-C103A, A20 ${ }^{\mathrm{OTU}}$ mice) to abrogate A20 DUB activity were generated (Lu et al. 2013; De et al. 2014; Wertz et al. 2015). These mice are grossly nor$\mathrm{mal}$ and do not develop the severe phenotype of A20-deficient mice, which die perinatally because of multiorgan inflammation and cachexia (Lee et al. 2000). However, A20 ${ }^{\mathrm{OTU}}$ mice were shown to be sensitized to TNF and LPS treatment, and to dextran sodium sulfate (DSS)-induced colitis and experimental autoimmune encephalomyelitis (EAE) (Lu et al. 2013; Wertz et al. 2015). De and colleagues, however, did not observe sensitization of A20 ${ }^{0 \mathrm{TU}}$ mice to LPS-induced pathology, nor did they observe any difference in TNF- or LPS-induced NF- $\kappa \mathrm{B}$ signaling or cell death in cells derived from these mice. They concluded that the DUB function of 
A20 in Cell Death, Inflammation, and Autoimmunity

A20 is dispensable for inflammatory signaling in vivo (De et al. 2014). A20 transgenic mice with a mutation in the E3 ligase activity (A20-C609A/ $\mathrm{C} 612 \mathrm{~A}, \mathrm{~A} 20^{\mathrm{ZnF} 4}$ mice) have also been generated, but these mice also develop normally without any spontaneous phenotype ( $\mathrm{Lu}$ et al. 2013; Wertz et al. 2015). Mouse embryo fibroblasts isolated from $\mathrm{A} 20^{\mathrm{OTU}}$ or $\mathrm{A} 20^{\mathrm{ZnF} 4}$ mice show increased K63-linked ubiquitination of RIPK1 and TNFR1, resulting in slightly increased mitogenactivated protein kinase (MAPK) and NF- $\kappa B$ signaling on TNF stimulation (Lu et al. 2013; Wertz et al. 2015). Together, these findings indicate that neither the DUB nor E3 ligase functions of A20 critically contribute to its anti-inflammatory function in vivo. Simultaneous inactivation of the OTU and ZnF4 domains may be required to fully abolish its function and phenocopy A20-deficient mice. However, recent in vitro and in vivo evidence indicates that $\mathrm{ZnF} 7$ of A20 plays a more prominent role. A20 was shown to impair IKK activation through a nonenzymatic mechanism based on its binding to polyubiquitin via ZnF7 (Skaug et al. 2011). Additional studies have shown that A20 recruitment to TNFR1 and NOD2-associated signaling complexes by binding of $\mathrm{ZnF7}$ to LUBAC-generated M1-linked polyubiquitin is required to inhibit downstream NF- $\kappa \mathrm{B}$ signaling (Iwai and Tokunaga 2009; Tokunaga et al. 2012; Verhelst et al. 2012; Draber et al. 2015). Recently, we generated mice bearing a mutation in $\mathrm{A} 20 \mathrm{ZnF} 7$ domain (A20-C764A/C767A, A20 ZnF7 mice) that abolishes its capacity to bind to M1-linked chains. These mice develop a spontaneous inflammatory arthritis and have reduced bodyweight and splenomegaly, showing an indispensable function for ZnF7 in A20-mediated suppression of inflammation in vivo (Polykratis et al. 2019). The ZnF7 mutation abolished the recruitment of A20 into the TNFR1 signaling complex, and reduced the amount of linear $\mathrm{Ub}$ chains within the complex (Draber et al. 2015; Polykratis et al. 2019). These observations indicate that A20 through its ZnF7 stabilizes M1 linkages in the TNFR1 signaling complex, shielding them from degradation by DUBs that are capable of cleaving linear Ub chains in signaling complexes. However, the spontaneous inflammatory phenotype of $\mathrm{A} 20^{\mathrm{ZnF} 7}$ mice is mild compared with the severe multiorgan inflammation and postnatal lethality seen in A20 knockout mice (Lee et al. 2000), suggesting that other domains also critically contribute to A20's anti-inflammatory function in vivo. Knockin mice with combined domain mutations may be required to fully inactivate A20 and phenocopy the A20 knockout.

\section{A20 IN THE REGULATION OF CELL DEATH}

In addition to its role in the regulation of $N F-\kappa B$ signaling, A20 also acts as a strong inhibitor of cell death in many cell types. Originally, A20 was identified as an inhibitor of TNF-induced apoptosis in endothelial cells (Dixit et al. 1990), but it can also limit apoptosis in thymocytes and fibroblasts (Lee et al. 2000), pancreatic $\beta$ cells (Liuwantara et al. 2006; Catrysse et al. 2015; Fukaya et al. 2016), hepatocytes (Catrysse et al. 2016), and intestinal epithelial cells (IECs) (Vereecke et al. 2010, 2014; Kattah et al. 2018; Slowicka et al. 2019).

Besides dying from caspase-dependent apoptosis, cells can also undergo caspase-independent but RIPK3- and MLKL-dependent necroptosis (Fig. 1; Pasparakis and Vandenabeele 2015; Ting and Bertrand 2016). A20 has also been proposed as an inhibitor of necroptosis in some cell types. A20-deficient T cells were shown to be more susceptible to anti-CD3/ CD28-induced cell death, independent of caspase activation but dependent on RIPK3 and the kinase activity of RIPK1 (Onizawa et al. 2015). In addition, RIPK3 deficiency or inhibition of RIPK1 could considerably delay the early postnatal lethality of A20 knockout mice (Onizawa et al. 2015; Newton et al. 2016). In contrast, MLKL deficiency could not rescue the early lethality of A20 knockout mice, questioning the role of necroptosis in the pathology of these mice (Newton et al. 2016). We recently showed that A20-deficient macrophages can die from RIPK1/RIPK3/MLKL-dependent necroptosis, causing inflammasome activation and arthritis development in myeloid-specific A20-deficient mice (Polykratis et al. 2019). Therefore, inhibi- 
tion of necroptosis is a critical anti-inflammatory function of A20 in vivo.

Finally, in some cell types, A20 may have proapoptotic functions. A20-deficient B cells and dendritic cells were shown to be protected from Fas-mediated cell death, most likely owing to the up-regulation of NF- $\mathrm{KB}$-dependent expression of antiapoptotic proteins such as Bcl-2 and Bcl-x (Tavares et al. 2010; Kool et al. 2011). A20 was also shown to sensitize smooth muscle cells to apoptosis through a mechanism depending on nitric oxide (NO) production (Patel et al. 2006).

Although it is clear that A20 is a key regulator of cell death, the mechanisms by which it does this are still incompletely understood. On activation of death receptors, A20 was shown to be recruited to the DISC, where it physically interacted with caspase- 8 . This interaction was suggested to prevent cullin3-mediated ubiquitination of caspase- 8 , inhibiting caspase- 8 activation and apoptosis (Jin et al. 2009). Alternatively, A20 was shown to inhibit TNF-induced apoptosis by preventing the recruitment of RIPK1 and TRADD to TNFR1, thereby inhibiting the recruitment of FADD and caspase- 8 ( $\mathrm{He}$ and Ting 2002). A20 was also shown to inhibit TNF-induced c-jun amino-terminal kinase (JNK) activation and apoptosis by targeting upstream ASK1 for ubiquitination and proteasomal degradation (Won et al. 2010). In the context of its protective function against necroptosis, A20 was shown to restrict RIPK3 ubiquitination, preventing the formation of RIPK1RIPK3 complexes and necroptosis induction (Onizawa et al. 2015).

Although these latter studies suggest that A20 acts as either a DUB or an E3 ligase, it is becoming more established that the nonenzymatic, polyubiquitin-binding function of A20 plays a prominent role in the regulation of cell death. A reduction of linear Ub chains within TNFR1 complex I was shown to promote cell death by inducing complex II assembly (Ikeda et al. 2011; Peltzer et al. 2014). The ZnF7 domain of A20 stabilizes linear Ub chains in complex I, inhibiting TNFR1-mediated cell death (Draber et al. 2015; Yamaguchi and Yamaguchi 2015). Hence, a mutation in the $\mathrm{ZnF7}$ domain of A20 abolishes the recruitment of A20 and reduces the amount of linear Ub chains in TNFR1 complex I (Tokunaga et al. 2012; Draber et al. 2015; Polykratis et al. 2019). Interestingly, the binding of M1-linked chains by ZnF7 in A20 was shown to protect these chains from degradation by CYLD, thereby stabilizing complex I and preventing the formation of the DISC (Fig. 1; Draber et al. 2015).

\section{MECHANISMS THAT REGULATE A20 ACTIVITY}

A20 expression and function is under the control of several regulatory mechanisms, viz. transcriptional, posttranscriptional, and posttranslational. In most cell types, A20 expression levels are low at steady state, but are rapidly upregulated in inflammatory conditions as a result of NF- $\mathrm{KB}$ activation (Krikos et al. 1992; Verstrepen et al. 2010). Different transcription factors work together to fine-tune the expression of A20 and the strength of NF- $\kappa \mathrm{B}$ signaling. DREAM (downstream regulatory element antagonist modulator) has been shown to constitutively repress expression of A20 by binding to downstream regulatory elements (DREs) in the A20 promoter, whereas upstream stimulatory factor 1 (USF1) has been shown to bind to the DRE-associated E-box domain in A20 to activate its expression in response to an inflammatory stimulus (Amir-Zilberstein and Dikstein 2008; Tiruppathi et al. 2014). Also, the orphan nuclear estrogen-related receptor $\alpha(E R R \alpha)$, a key metabolic regulator, has been shown to promote expression of A20 in mice (Yuk et al. 2015). ERR $\alpha$ binds to an Esrra consensus motif in the A20 promoter, inducing expression of A20 and suppressing NF- $\mathrm{\kappa B}$ signaling in LPS-stimulated macrophages (Yuk et al. 2015). Finally, the histone methyltransferase Ash1l (absent small or homeotic-like) was shown to enhance expression of A20 through H3K4 methylation of the A20 promoter, suppressing inflammatory signaling (Xia et al. 2013).

$\mathrm{T}$ lymphocytes constitutively express high levels of A20, which are down-regulated on TCR activation and NF- $\mathrm{\kappa B}$ induction (Tewari et al. 1995). Proteasomal degradation of A20, 
A20 in Cell Death, Inflammation, and Autoimmunity

as well as its cleavage by the paracaspase MALT1, contribute to the down-regulation of A20 following TCR stimulation (Coornaert et al. 2008; Duwel et al. 2009). Methylation of the $A 20$ promotor, preventing expression of $A 20$ and stimulating constitutive NF- $\kappa \mathrm{B}$ activation, has been observed in several types of lymphomas (Honma et al. 2009; Chanudet et al. 2010).

Expression of A20 is also regulated by several microRNAs (miRs). In diffuse large B-cell lymphomas, miR-125a and miR-125b were shown to down-regulate expression of A20, leading to constitutive activation of NF- $\kappa \mathrm{B}, \mathrm{B}$-cell proliferation, and lymphomagenesis (Kim et al. 2012). miR-125-mediated inhibition of A20 has also been shown in lung infection and in chronic obstructive pulmonary disease (COPD) (Hsu et al. 2017). miR-19, miR-29, miR-221, and miR-let-7 are other miRNAs that have been shown to suppress A20, leading to enhanced $\mathrm{NF}-\kappa \mathrm{B}$ signaling and/or cell death (Wang et al. 2011; Gantier et al. 2012; Balkhi et al. 2013; Kumar et al. 2015; Langsch et al. 2016; Zhao et al. 2016).

A20 interacts with different partners to perform its regulatory functions. Multiple Ubbinding proteins have been described that bind to A20 and recruit it to its substrates. A20-binding inhibitor of NF- $\mathrm{B}$ (ABIN1) was shown to recruit A20 to polyubiquitinated NEMO to remove Ub chains from NEMO (Heyninck et al. 1999; Mauro et al. 2006; Wagner et al. 2008). Tax1-binding protein 1 (TAX1BP1) negatively regulates $\mathrm{NF}-\kappa \mathrm{B}$ signaling by recruiting A20 to TRAF6 and RIPK1 (Shembade et al. 2007; Iha et al. 2008). Itch and RING finger protein 11 (RNF11) have been shown to function as subunits of an A20 Ub-editing complex to inhibit NF- $\kappa B$ signaling (Shembade et al. 2008, 2009).

The activity of A20 is also regulated by posttranslational modifications. On receptor activation, A20 is phosphorylated at Ser381 by IKK2, increasing its inhibitory capacity (Hutti et al. 2007). Although A20 hydrolyzes K63-linked Ub chains in vivo via its OTU domain, recombinant A20 expressed in bacteria preferentially cleaves K48-linked chains in vitro (Komander and Barford 2008; Lin et al. 2008). The phosphorylation status of A20 appears to account for this discrepancy because phosphorylated A20 was shown to efficiently cleave K63-linked chains in vitro (Wertz et al. 2015). In T lymphocytes, A20 can be ubiquitinated by the E3 Ub ligase RNF114, thereby stabilizing A20 and restraining NF- $\kappa \mathrm{B}$ responses (Rodriguez et al. 2014). In smooth muscle cells exposed to high glucose levels, A20 can be O-glycosylated and subsequently ubiquitinated and targeted for proteasomal degradation (Shrikhande et al. 2010). Finally, A20 is also regulated by reversible oxidation of the catalytic cysteine residue, modifying its activation state (Kulathu et al. 2013; Lee et al. 2013).

\section{A20 AS A DISEASE SUSCEPTIBILITY GENE}

Several single-nucleotide polymorphisms (SNPs) in or near the A20 gene have been linked to a variety of autoimmune and inflammatory diseases, including systemic lupus erythematosus (SLE), rheumatoid arthritis, psoriasis, type 1 diabetes, Crohn's disease, celiac disease, coronary artery disease in type 2 diabetes, systemic sclerosis, and Sjogren's syndrome (Ma and Malynn 2012; Catrysse et al. 2014). Associations have also been reported for autoimmune hepatitis (de Boer et al. 2014) and primary biliary cirrhosis (Cordell et al. 2015). Most of these disease-associated variants are located in upstream or downstream noncoding regions or in intronic regions of the A20 gene, possibly affecting the expression of A20 (Graham et al. 2008; Adrianto et al. 2011). Downstream SNPs can influence expression of A20 by affecting the function of cell- and activation-specific enhancers. For example, deletion of a downstream region containing four enhancers was shown to significantly reduce expression of A20, resulting in enhanced inflammatory responses (Sokhi et al. 2018). One of these enhancers harbors the $\mathrm{TT}>\mathrm{A}$ variant that was linked to SLE susceptibility (Adrianto et al. 2011; Wang et al. 2013a). Deletion of this TT $>$ A enhancer in mice induced spontaneous inflammatory arthritis, thereby establishing the importance of this enhancer in preventing inflammatory pathology and autoimmunity (Sokhi et al. 2018). Besides the many noncod- 
ing variants, two SNPs have been identified in exon 3 of $A 20$ that induce nonsynonymous mutations (rs5029941/A125V and rs2230926/ F127C) (Musone et al. 2008; Lodolce et al. 2010). These mutations are suggested to affect the DUB activity of A20, although this has not been evaluated in vivo.

Recently, whole-exome sequencing identified heterozygous loss-of-function mutations in the A20/TNFAIP3 gene (A20 haploinsufficiency, HA20) of patients with a rare, early-onset autoinflammatory syndrome (Zhou et al. 2016). These nonsense and frameshift mutations are all localized in the DUB or the $\mathrm{ZnF} 4$ domains of A20, and the mutant proteins are likely unstable because A20 was not detected in cells from HA20 patients (Zhou et al. 2016). Patients' cells displayed increased NF- $\kappa$ B signaling, NLRP3 inflammasome activity, and increased expression of proinflammatory cytokines (Zhou et al. 2016). Several other cases of germline HA20 have since been identified in patients with early-onset autoimmune disease (Fig. 3; Table 1; Aeschlimann et al. 2018; Duncan et al. 2018). Overall, HA20 patients develop recurrent oral, genital, and/or gastrointestinal ulcers, musculoskeletal and gastrointestinal problems, episodic fever, and recurrent infections. However, disease severity is strongly patient-dependent, ranging from very mild disease to severe multiorgan inflammation, and treatment regimens need to be adjusted to disease severity (Aeschlimann et al. 2018).
Finally, $A 20$ has been identified as a tumor suppressor gene, because biallelic somatic mutations in A20 are frequently observed in several B-cell lymphomas, including MALT lymphoma, Hodgkin's lymphoma, diffuse large B-cell lymphoma, and follicular lymphoma. These loss-of-function mutations are associated with constitutive NF- $\mathrm{BB}$ signaling and uncontrolled cell proliferation (Compagno et al. 2009; Honma et al. 2009; Kato et al. 2009; Novak et al. 2009; Schmitz et al. 2009; Okosun et al. 2014). Biallelic mutations in A20 have also been identified in Sézary syndrome, an aggressive variant of cutaneous T-cell lymphoma (Braun et al. 2011). However, A20 has also been described as a tumor promotor, likely connected to its antiapoptotic functions, and high levels of A20 have been detected in glioma (Guo et al. 2009), glioblastoma (Hjelmeland et al. 2010), and acute lymphoblastic leukemia (Chen et al. 2015). Furthermore, A20 was shown to be up-regulated in human basal-like breast cancers in which it promotes epithelial-mesenchymal transition (EMT) through monoubiquitination and nuclear stabilization of SNAIL1, a transcription factor that drives EMT (Lee et al. 2017).

\section{TISSUE-SPECIFIC FUNCTIONS OF A20}

A20 is an important anti-inflammatory protein that acts as a direct inhibitor of NF- $\mathrm{KB}$ signaling, or as an inhibitor of proinflammatory cell death. However, inflammatory signaling pathways and

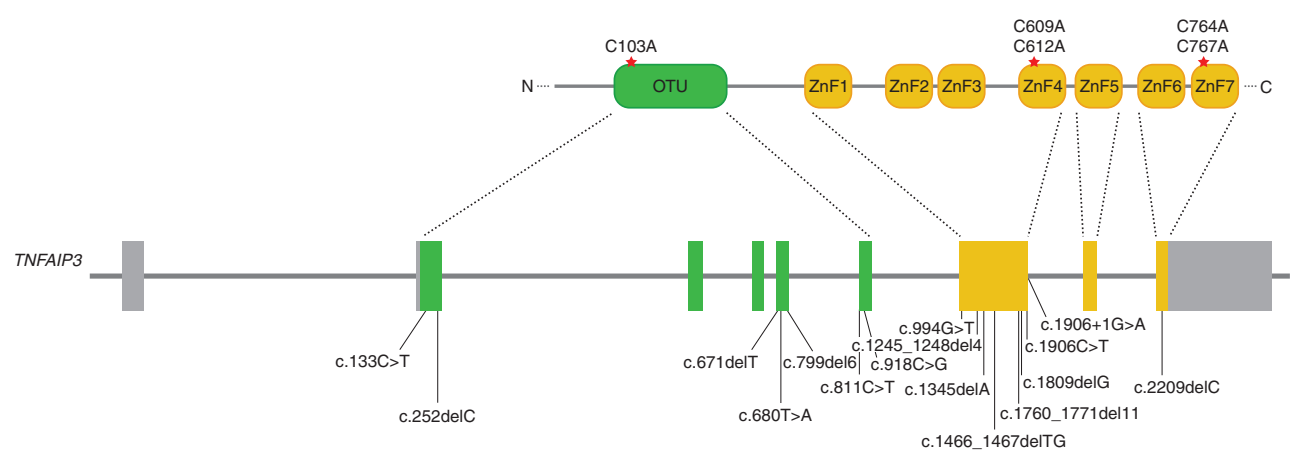

Figure 3. Schematic representation of the TNFAIP3 gene indicating mutations causing A20 haploinsufficiency (HA20). Exons (1-9) are represented as rectangles. Exons encoding the ovarian tumor (OTU) domain are depicted in green and exons encoding the $\mathrm{ZnF}$ domains are depicted in orange; noncoding exons are shown in gray. HA20 mutations depicted in the figure are also listed in Table 1. 
A20 in Cell Death, Inflammation, and Autoimmunity

Table 1. Overview of identified HA20 mutations

\begin{tabular}{|c|c|c|c|}
\hline cDNA alteration & $\begin{array}{l}\text { Amino acid } \\
\text { alteration }\end{array}$ & Domain & References \\
\hline c. $680 \mathrm{~T}<\mathrm{A}$ & p.Leu227* & Ovarian tumor (OTU) & Zhou et al. 2016; Aeschlimann et al. 2018 \\
\hline c.671delT & p.Phe224Serfs* 4 & OTU & \\
\hline c. $811 \mathrm{C}>\mathrm{T}$ & p.Arg271* & OTU & \\
\hline c.1809delG & p.Thr604Argfs* 93 & $\mathrm{ZnF} 4$ & \\
\hline c. $918 \mathrm{C}>\mathrm{G}$ & p.Tyr306* & OTU & \\
\hline c.799delG & p.Pro268Leufs*19 & OTU & \\
\hline c.252delC & p.Trp85Gly $f s^{*} 11$ & OTU & Shigemura et al. 2016; Ohnishi et al. 2017; \\
\hline c. $133 \mathrm{C}>\mathrm{T}$ & p.Arg $45^{*}$ & OTU & Takagi et al. 2017; Kadowaki et al. 2018 \\
\hline c.1760_1770del11 & p.Ala588Valfs* 80 & Between $\mathrm{ZnF3-4}$ & \\
\hline c.1345delA & p.Asn $449 \mathrm{Thrfs} s^{*} 28$ & Between $\mathrm{ZnF} 1-2$ & \\
\hline c. $1906+1 G>A$ & p.Phe637Glu*2 & Between ZnF4-5 & \\
\hline c.2209delC & p.Gln737Ser $f s^{*} 79$ & ZnF6 & \\
\hline c. $2088+5 \mathrm{G}>\mathrm{C}$ & p.His636Glufs ${ }^{*} 55$ & $\mathrm{ZnF} 4$ & \\
\hline c. $728 \mathrm{G}>\mathrm{A}$ & p.Cys243Tyr & OTU & \\
\hline c.1245-1248del4 & p.Lys $417 \operatorname{Ser} f s^{*} 4$ & Between $\mathrm{ZnF1-2}$ & \\
\hline c. $994 \mathrm{G}>\mathrm{T}$ & p.Glu332* & OTU & Berteau et al. 2019 \\
\hline c.1466_1467delTG & p.Val489Alafs*7 & $\mathrm{ZnF} 2$ & Duncan et al. 2018 \\
\hline c. $1906 \mathrm{C}>\mathrm{T}$ & p.His636fs* 1 & $\mathrm{ZnF} 4$ & Lawless et al. 2018 \\
\hline
\end{tabular}

cell death are differentially regulated in different cell types; hence, A20 may have cell-specific contributions to prevent inflammation and disease pathogenesis. Because A20 knockout mice die prematurely because of severe multiorgan inflammation (Lee et al. 2000), conditional, lineage-specific knockout strategies are needed to unravel the tissue-specific functions of A20. Several tissue-specific A20-deficient mice have been generated in recent years that clearly show the importance of A20 in maintaining tissue homeostasis by regulating inflammatory responses and cell death (Table 2). In this section, we refer to a number of recent mouse studies that provide new information on the role of A20 in the prevention of cell death and its implications for inflammatory pathology.

Mice lacking A20 in their myeloid cells $\left(\mathrm{A} 20^{\mathrm{Myel}-\mathrm{KO}}\right)$ develop spontaneous polyarthritis with many characteristics of human rheumatoid arthritis, including autoantibodies against type II collagen and rheumatoid arthritis-associated cytokines (Matmati et al. 2011). The arthritis phenotype in $\mathrm{A} 20^{\text {Myel-KO }}$ mice was shown to require IL-6 and TLR4-MyD88, but not TNF. Primary macrophages from these mice show sustained NF- $\kappa B$ activation in response to lipo- polysaccharide (LPS), in agreement with a role for A20 as an inhibitor of NF- $\kappa B$ signaling (Matmati et al. 2011). A20-deficient macrophages also express higher levels of STAT1 and STAT1-dependent genes upon stimulation with interferon $\gamma$ (IFN- $\gamma$ ) or IL-6. Inhibition of JAK-STAT signaling in vivo with the JAK inhibitor tofacitinib was shown to suppress the development of enthesitis in $\mathrm{A} 20^{\text {Myel-KO }}$ mice (De Wilde et al. 2017). Interestingly, myeloid A20 deficiency was also shown to promote osteoclastogenesis, suggesting a role for A20 in regulating receptor activator of the NF- $\mathrm{KB}$ (RANK)-induced NF- $\mathrm{KB}$ signaling. Further studies, preferably using osteoclast-specific A20 targeting, are needed to confirm a direct regulatory role of A20 in regulating osteoclastogenesis and bone formation.

Arthritis development in $\mathrm{A} 20^{\mathrm{Myel}-\mathrm{KO}}$ mice relies on activation of the Nlrp3 inflammasome and IL-1R signaling (Vande Walle et al. 2014). Thus, A20 ${ }^{\text {Myel-KO }}$ mice crossed into an Nlrp3-, caspase-1/11-, or IL-1R-deficient background no longer develop arthritis. Primary A20-deficient macrophages show enhanced Nlrp3 inflammasome-mediated caspase- 1 activation, pyroptosis, and IL-1 $\beta$ secretion by soluble and 
Table 2. Phenotypes of tissue-specific A20 knockout and A20 transgenic mice

\begin{tabular}{|c|c|c|c|}
\hline Cell type & $\mathrm{OE} / \mathrm{KO}$ & Phenotype & References \\
\hline \multirow[t]{2}{*}{ Myeloid cells } & $\mathrm{KO}$ & Spontaneous severe destructive polyarthritis & $\begin{array}{l}\text { Matmati et al. 2011; } \\
\text { Vande Walle et al. } \\
\text { 2014; De Wilde et al. } \\
\text { 2017; Polykratis et al. } \\
2019\end{array}$ \\
\hline & $\mathrm{KO}$ & Protected from influenza A virus infection & Maelfait et al. 2012 \\
\hline \multirow[t]{3}{*}{ Dendritic cells } & $\mathrm{KO}$ & Spontaneous colitis, IBD-associated arthritis & Hammer et al. 2011 \\
\hline & $\mathrm{KO}$ & Systemic autoimmunity resembling SLE & Kool et al. 2011 \\
\hline & $\mathrm{KO}$ & Multiorgan inflammation, hypersensitive to LPS & Xuan et al. 2015 \\
\hline B cells & $\mathrm{KO}$ & $\begin{array}{l}\text { Development of autoimmune syndrome in older mice } \\
\text { (autoreactive immunoglobulins, glomerular } \\
\text { immunoglobulin deposits, } \uparrow \text { germinal center B cells, B-cell } \\
\text { resistance to Fas-mediated cell death) }\end{array}$ & $\begin{array}{l}\text { Tavares et al. 2010; Chu } \\
\text { et al. 2011; Hovelmeyer } \\
\text { et al. } 2011\end{array}$ \\
\hline \multirow[t]{4}{*}{ T cells } & $\mathrm{KO}$ & No spontaneous phenotype, $\downarrow$ iNKT cell numbers & Drennan et al. 2016 \\
\hline & $\mathrm{KO}$ & No spontaneous phenotype, protected from EAE & Onizawa et al. 2015 \\
\hline & $\mathrm{KO}$ & $\begin{array}{l}\text { Lymphadenopathy but no detectable pathology, enhanced } \\
\text { antitumor activity }\end{array}$ & Giordano et al. 2014 \\
\hline & $\mathrm{KO}$ & $\uparrow$ Treg cell numbers & Fischer et al. 2017 \\
\hline HSC & $\mathrm{KO}$ & $\begin{array}{l}\text { Loss of HSC quiescence causing anemia, lymphopenia, and } \\
\text { postnatal lethality }\end{array}$ & Nakagawa et al. 2015 \\
\hline Mast cells & $\mathrm{KO}$ & $\begin{array}{l}\text { Hypersensitive to allergic airway responses and collagen- } \\
\text { induced arthritis }\end{array}$ & Heger et al. 2014 \\
\hline \multirow[t]{4}{*}{ IEC } & $\mathrm{KO}$ & $\begin{array}{l}\text { No spontaneous pathology, enhanced susceptibility to DSS- } \\
\text { induced colitis and to TNF toxicity }\end{array}$ & $\begin{array}{l}\text { Vereecke et al. 2010; } \\
\text { Kattah et al. } 2018\end{array}$ \\
\hline & $\mathrm{OE}$ & Protected from LPS-induced barrier disruption & Kolodziej et al. 2011 \\
\hline & $\mathrm{OE}$ & $\begin{array}{l}\text { Protected from DSS-induced IEC death and barrier } \\
\text { disruption }\end{array}$ & Rhee et al. 2012 \\
\hline & $\mathrm{OE}$ & $\begin{array}{l}\text { Hypersensitive to TNF-induced IEC death and systemic } \\
\text { inflammation }\end{array}$ & $\begin{array}{l}\text { Garcia-Carbonell et al. } \\
\quad 2018\end{array}$ \\
\hline $\begin{array}{l}\text { IEC + myeloid } \\
\text { cells }\end{array}$ & $\mathrm{KO}$ & Spontaneous severe ileitis and colitis, colorectal cancer & Vereecke et al. 2014 \\
\hline Hepatocytes & $\mathrm{KO}$ & $\begin{array}{l}\text { Chronic liver inflammation, enhanced sensitivity to TNF and } \\
\text { LPS toxicity and to chemically and high fat diet-induced } \\
\text { hepatocarcinogenesis }\end{array}$ & Catrysse et al. 2016 \\
\hline Keratinocytes & & $\begin{array}{l}\text { Keratinocyte hyperproliferation, ectodermal organ } \\
\text { abnormalities, sensitized to experimental psoriasis, and } \\
\text { atopic dermatitis }\end{array}$ & $\begin{array}{l}\text { Lippens et al. 2011; Devos } \\
\text { et al. } 2019\end{array}$ \\
\hline Neurons & $\mathrm{KO}$ & No phenotype & McGuire et al. 2013 \\
\hline $\begin{array}{l}\text { CNS } \\
\text { progenitor } \\
\text { cells }\end{array}$ & $\mathrm{KO}$ & & \\
\hline Microglia & $\mathrm{KO}$ & $\begin{array}{l}\uparrow \text { Microglia numbers and microglia activation, hypersensitive } \\
\text { LPS and EAE }\end{array}$ & Voet et al. 2018 \\
\hline Astrocytes & $\mathrm{KO}$ & Hypersensitive to EAE & Wang et al. 2013b \\
\hline $\begin{array}{l}\text { Airway } \\
\text { epithelial } \\
\text { cells }\end{array}$ & $\mathrm{KO}$ & $\begin{array}{l}\text { Protected from influenza A virus infection, highly sensitive to } \\
\text { allergic airway inflammation }\end{array}$ & $\begin{array}{l}\text { Schuijs et al. 2015; } \\
\quad \text { Maelfait et al. } 2016\end{array}$ \\
\hline $\begin{array}{l}\text { Pancreatic } \beta \\
\quad \text { cells }\end{array}$ & $\mathrm{KO}$ & No phenotype & $\begin{array}{l}\text { Liuwantara et al. } 2006 ; \\
\text { Catrysse et al. } 2015 ; \\
\text { Fukaya et al. } 2016\end{array}$ \\
\hline
\end{tabular}

OE, Overexpression; KO, knockout; IBD, inflammatory bowel disease; SLE, systemic lupus erythematosus; LPS, lipopolysaccharide; iNKT, invariant natural killer T cell; EAE, experimental autoimmune encephalomyelitis; HSC, hematopoietic stem cell; IEC, intestinal epithelial cell; DSS, dextran sodium sulfate; TNF, tumor necrosis factor. 
crystalline Nlrp3 stimuli. Myeloid-specific ASC deficiency substantially ameliorated arthritis in A20 $0^{\text {Myel-KO }}$ mice, indicating that cell-intrinsic inflammasome activation in A20-deficient myeloid cells drives pathology (Polykratis et al. 2019). Although A20 was shown to regulate Nlrp3 inflammasome activation in vitro by negatively regulating $\mathrm{NF}-\kappa \mathrm{B}$-dependent priming needed for optimal expression of pro-IL-1 $\beta$ and Nlrp3 (Vande Walle et al. 2014), inhibition of IKK/NF- $\kappa B$ signaling in A20-deficient myeloid cells was not sufficient to prevent arthritis development (Polykratis et al. 2019). Rather, regulation of cell death, and particularly of necroptosis, was identified as the key anti-inflammatory function of A20 in preventing the development of arthritis. Indeed, RIPK1/ RIPK3/MLKL-dependent macrophage necroptosis was shown to induce inflammasome activation, IL-1 $\beta$ production, and arthritis development in A20 $0^{\mathrm{Myel}-\mathrm{KO}}$ mice (Polykratis et al. 2019). These data are supported by real-time single-cell imaging experiments, which show that IL-1 $\beta$ is secreted exclusively by dying A20-deficient macrophages. An earlier study had suggested that inflammasome activation and IL- $1 \beta$ release in A20-deficient macrophages occurs in the absence of cell death (Duong et al. 2015). A20 has also been shown to control microglia activation and neuroinflammation via regulation of Nlrp3 inflammasome activation (Voet et al. 2018). How A20 regulates Nlrp3 activation, and whether this is directly or indirectly preventing microglia cell death, needs further investigation.

An important prosurvival role for A20 has also been shown in IECs. Although IEC-specific A20 knockout mice (A20 ${ }^{\text {IEC-KO})}$ do not develop spontaneous disease, they are highly susceptible to DSS-induced colitis and are hypersensitive to a normally sublethal dose of TNF. IECs from A20 ${ }^{\mathrm{IEC}-\mathrm{KO}}$ mice are hypersensitive to apoptosis, leading to loss of intestinal barrier integrity and bacterial infiltration in A20 ${ }^{\mathrm{IEC}-\mathrm{KO}}$ mice (Vereecke et al. 2010). The antiapoptotic property of A20. in IECs was confirmed in transgenic mice with IEC-specific overexpression of A20. These mice are protected from DSS- and LPSinduced IEC apoptosis and loss of barrier func- tion (Kolodziej et al. 2011; Rhee et al. 2012), but are highly susceptible to TNF-induced IEC apoptosis, intestinal damage, and systemic inflammation. The latter phenotype required RIPK1 and caspase-8, and was mediated by $\mathrm{ZnF7}$ of A20 (Garcia-Carbonell et al. 2018). Thus, A20 binding to linear $\mathrm{Ub}$ appears to stabilize the Ripoptosome and potentiate its apoptosis-inducing activity (Garcia-Carbonell et al. 2018). Although A20 ${ }^{\text {IEC-KO }}$ mice do not develop a spontaneous intestinal phenotype (Vereecke et al. 2010; Kattah et al. 2018), mice lacking A20 in both IECs and myeloid cells develop severe ileitis and colitis, associated with epithelial apoptosis and hyperproliferation, which eventually leads to the development of colon cancer (Vereecke et al. 2014). Combined IEC-specific deletion of A20 and the A20-interacting protein ABIN1 also induces spontaneous intestinal inflammation and severe pathology because of the caspase- 8 and RIPK1-dependent death of IECs (Kattah et al. 2018). Similarly, combined deletion of A20 and Atg16L1 in IECs induces spontaneous inflammatory bowel disease (IBD)-like pathology caused by IEC apoptosis (Slowicka et al. 2019). Interestingly, both $A B I N-1$ and Atg16L1 have been associated with IBD (Hampe et al. 2007; Rioux et al. 2007; Jostins et al. 2012) and have been shown to bind to A20 and to $\mathrm{Ub}$ (Wagner et al. 2008; Fujita et al. 2013; Slowicka et al. 2019). Collectively, these data suggest that inflammatory signaling and autophagy cooperatively control intestinal homeostasis by preventing the death of enterocytes that would compromise intestinal barrier integrity.

Finally, A20 was shown to have hepatoprotective activities. Hepatocyte-specific A20-deficient mice (A20 ${ }^{\mathrm{LPC}-\mathrm{KO}}$ ) spontaneously develop mild liver inflammation and steatosis, but succumb to a normally sublethal dose of TNF owing to excessive hepatocyte apoptosis. Moreover, chronic liver inflammation and enhanced hepatocyte apoptosis in A20 ${ }^{\mathrm{LPC}-\mathrm{KO}}$ mice increased their susceptibility to chemically and high fat diet-induced hepatocellular carcinoma development (Catrysse et al. 2016). A20 overexpression in liver has been shown to be protective in models of hepatectomy and acute toxic hepatitis, owing to antiapoptotic and anti- 
inflammatory mechanisms (Arvelo et al. 2002; Ramsey et al. 2009; Damrauer et al. 2011; da Silva et al. 2013).

\section{CONCLUDING REMARKS}

A20 was identified nearly 30 years ago (Dixit et al. 1990; Opipari et al. 1990) and has emerged as a critical regulator of inflammatory signaling to preserve tissue immune homeostasis. Although inhibition of $\mathrm{NF}-\kappa \mathrm{B}$ activation has long been considered the key anti-inflammatory function of A20, it is becoming more evident that its role in preventing cell death is a major mechanism for suppressing inflammation. However, A20 may have different modes of action in different cell types given the phenotypes of different tissue-specific A20 knockout mice. $\mathrm{NF}-\kappa \mathrm{B}$ inhibitory activities, antiapoptotic functions, as well as antinecroptotic functions, and even proapoptotic functions have been identified in different cell types. Mechanistically, A20 has been proposed to function as a DUB, but the physiological relevance of its function as a DUB has been challenged by the finding that DUBinactive A20 knockin mice do not develop spontaneous inflammatory disease. Recent evidence suggests that A20 mainly acts as a Ub-binding protein via its $\mathrm{ZnF}$ domain, which primarily recruits A20 into specific protein complexes to prevent downstream signaling. However, finetuning of signaling may require additional A20-specific activities, including A20 DUB activity. Generation of knockin mice with combined domain mutations will be essential to dissect the importance of and redundancies between the different functional domains of A20. Such studies will help to better understand the role of A20 in inflammation and immunity, which might help to develop new therapeutics for the treatment of disease.

\section{ACKNOWLEDGMENTS}

A.M. is supported by a grant from the Concerted Research Actions (GOA) of the Ghent University. Research in the G.v.L. laboratory is supported by research grants from the Research Foundation - Flanders (FWO), the Geneeskun- dige Stichting Koningin Elisabeth (GSKE), the CBC Banque Prize, the Charcot Foundation, the Belgian Foundation against Cancer, and Kom op tegen Kanker.

\section{REFERENCES}

Adrianto I, Wen F, Templeton A, Wiley G, King JB, Lessard CJ, Bates JS, Hu Y, Kelly JA, Kaufman KM, et al. 2011. Association of a functional variant downstream of TNFAIP3 with systemic lupus erythematosus. Nat Genet 43: 253-258. doi:10.1038/ng.766

Aeschlimann FA, Batu ED, Canna SW, Go E, Gül A, Hoffmann P, Leavis HL, Ozen S, Schwartz DM, Stone DL, et al. 2018. A20 haploinsufficiency (HA20): Clinical phenotypes and disease course of patients with a newly recog-

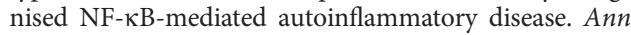
Rheum Dis 77: 728-735. doi:10.1136/annrheumdis2017-212403

Amir-Zilberstein L, Dikstein R. 2008. Interplay between E-box and NF- $\mathrm{KB}$ in regulation of A20 gene by DRB sensitivity-inducing factor (DSIF). J Biol Chem 283: 1317-1323. doi:10.1074/jbc.M706767200

Arvelo MB, Cooper JT, Longo C, Daniel S, Grey ST, Mahiou J, Czismadia E, Abu-Jawdeh G, Ferran C. 2002. A20 protects mice from D-galactosamine/lipopolysaccharide acute toxic lethal hepatitis. Hepatology 35: 535-543. doi:10.1053/jhep.2002.31309

Balkhi MY, Iwenofu OH, Bakkar N, Ladner KJ, Chandler DS, Houghton PJ, London CA, Kraybill W, Perrotti D, Croce CM, et al. 2013. miR-29 acts as a decoy in sarcomas to protect the tumor suppressor A20 mRNA from degradation by HuR. Sci Signal 6: ra63. doi:10.1126/scisignal .2004177

Berteau F, Rouvière B, Nau A, Le Berre R, Sarrabay G, Touitou I, de Moreuil C. 2019. A20 haploinsufficiency (HA20): Clinical phenotypes and disease course of patients with a newly recognised NF- $\kappa \mathrm{B}$-mediated autoinflammatory disease. Ann Rheum Dis 78: e35. doi:10.1136/ annrheumdis-2018-213347

Boone DL, Turer EE, Lee EG, Ahmad RC, Wheeler MT, Tsui C, Hurley P, Chien M, Chai S, Hitotsumatsu O, et al. 2004. The ubiquitin-modifying enzyme A20 is required for termination of Toll-like receptor responses. Nat Immunol 5: 1052-1060. doi:10.1038/ni1110

Bosanac I, Wertz IE, Pan B, Yu C, Kusam S, Lam C, Phu L, Phung Q, Maurer B, Arnott D, et al. 2010. Ubiquitin binding to A20 $\mathrm{ZnF} 4$ is required for modulation of NFкB signaling. Mol Cell 40: 548-557. doi:10.1016/j.molcel .2010 .10 .009

Braun FC, Grabarczyk P, Möbs M, Braun FK, Eberle J, Beyer M, Sterry W, Busse F, Schroder J, Delin M, et al. 2011. Tumor suppressor TNFAIP3 (A20) is frequently deleted in Sézary syndrome. Leukemia 25: 1494-1501. doi:10 $.1038 /$ leu.2011.101

Catrysse L, Vereecke L, Beyaert R, van Loo G. 2014. A20 in inflammation and autoimmunity. Trends Immunol 35: 22-31. doi:10.1016/j.it.2013.10.005

Catrysse L, Fukaya M, Sze M, Meyerovich K, Beyaert R, Cardozo AK, van Loo G. 2015. A20 deficiency sensitizes 
pancreatic $\beta$ cells to cytokine-induced apoptosis in vitro but does not influence type 1 diabetes development in vivo. Cell Death Dis 6: e1918. doi:10.1038/cddis.2015.301

Catrysse L, Farhang Ghahremani M, Vereecke L, Youssef SA, McGuire C, Sze M, Weber A, Heikenwalder M, de Bruin A, Beyaert R, et al. 2016. A20 prevents chronic liver inflammation and cancer by protecting hepatocytes from death. Cell Death Dis 7: e2250. doi:10.1038/cddis.2016 .154

Chanudet E, Huang Y, Ichimura K, Dong G, Hamoudi RA, Radford J, Wotherspoon A, Isaacson PG, Ferry J, Du MQ. 2010. A20 is targeted by promoter methylation, deletion and inactivating mutation in MALT lymphoma. Leukemia 24: 483-487. doi:10.1038/leu.2009.234

Chen S, Xing H, Li S, Yu J, Li H, Liu S, Tian Z, Tang K, Rao Q, Wang M, et al. 2015. Up-regulated A20 promotes proliferation, regulates cell cycle progression and induces chemotherapy resistance of acute lymphoblastic leukemia cells. Leukemia Res 39: 976-983. doi:10.1016/j.leukres .2015 .06 .004

Chu Y, Vahl JC, Kumar D, Heger K, Bertossi A, Wojtowicz E, Soberon V, Schenten D, Mack B, Reutelshofer M, et al. 2011. B cells lacking the tumor suppressor TNFAIP3/A20 display impaired differentiation and hyperactivation and cause inflammation and autoimmunity in aged mice. Blood 117: 2227-2236. doi:10.1182/blood-2010-09306019

Compagno M, Lim WK, Grunn A, Nandula SV, Brahmachary M, Shen Q, Bertoni F, Ponzoni M, Scandurra M, Califano A, et al. 2009. Mutations of multiple genes cause deregulation of NF- $\mathrm{kB}$ in diffuse large B-cell lymphoma. Nature 459: 717-721. doi:10.1038/nature07968

Coornaert B, Baens M, Heyninck K, Bekaert T, Haegman M, Staal J, Sun L, Chen ZJ, Marynen P, Beyaert R. 2008. T cell antigen receptor stimulation induces MALT1 paracaspase-mediated cleavage of the NF- $\mathrm{KB}$ inhibitor A20. Nat Immunol 9: 263-271. doi:10.1038/ni1561

Cordell HJ, Han Y, Mells GF, Li Y, Hirschfield GM, Greene CS, Xie G, Juran BD, Zhu D, Qian DC, et al. 2015. International genome-wide meta-analysis identifies new primary biliary cirrhosis risk loci and targetable pathogenic pathways. Nat Commun 6: 8019. doi:10.1038/ ncomms 9019

Damrauer SM, Studer P, da Silva CG, Longo CR, Ramsey HE, Csizmadia E, Shrikhande GV, Scali ST, Libermann TA, Bhasin MK, et al. 2011. A20 modulates lipid metabolism and energy production to promote liver regeneration. PLoS ONE 6: e17715. doi:10.1371/journal.pone .0017715

da Silva CG, Studer P, Skroch M, Mahiou J, Minussi DC, Peterson CR, Wilson SW, Patel VI, Ma A, Csizmadia E, et al. 2013. A20 promotes liver regeneration by decreasing SOCS3 expression to enhance IL-6/STAT3 proliferative signals. Hepatology 57: 2014-2025. doi:10.1002/hep .26197

De A, Dainichi T, Rathinam CV, Ghosh S. 2014. The deubiquitinase activity of A20 is dispensable for NF- $\mathrm{KB}$ signaling. EMBO Rep 15: 775-783. doi:10.15252/embr .201338305

de Boer YS, van Gerven NM, Zwiers A, Verwer BJ, van Hoek $B$, van Erpecum KJ, Beuers U, van Buuren HR, Drenth JP, den Ouden JW, et al. 2014. Genome-wide association study identifies variants associated with autoimmune hepatitis type 1. Gastroenterology 147: 443-452.e5. doi:10.1053/j.gastro.2014.04.022

Devos M, Mogilenko DA, Fleury S, Gilbert B, Becquart C, Quemener S, Dehondt H, Tougaard P, Staels B, Bachert C, et al. 2019. Keratinocyte expression of A20/TNFAIP3 controls skin inflammation associated with atopic dermatitis and psoriasis. J Invest Dermatol 139: 135-145. doi:10 $.1016 /$ j.jid.2018.06.191

De Wilde K, Martens A, Lambrecht S, Jacques P, Drennan MB, Debusschere K, Govindarajan S, Coudenys J, Verheugen E, Windels F, et al. 2017. A20 inhibition of STAT1 expression in myeloid cells: A novel endogenous regulatory mechanism preventing development of enthesitis. Ann Rheum Dis 76: 585-592. doi:10.1136/annrheum dis-2016-209454

Dixit VM, Green S, Sarma V, Holzman LB, Wolf FW, O'Rourke K, Ward PA, Prochownik EV, Marks RM. 1990. Tumor necrosis factor- $\alpha$ induction of novel gene products in human endothelial cells including a macrophage-specific chemotaxin. J Biol Chem 265: 2973-2978.

Draber P, Kupka S, Reichert M, Draberova H, Lafont E, de Miguel D, Spilgies L, Surinova S, Taraborrelli L, Hartwig T, et al. 2015. LUBAC-recruited CYLD and A20 regulate gene activation and cell death by exerting opposing effects on linear ubiquitin in signaling complexes. Cell Rep 13: 2258-2272. doi:10.1016/j.celrep.2015.11.009

Drennan MB, Govindarajan S, Verheugen E, Coquet JM, Staal J, McGuire C, Taghon T, Leclercq G, Beyaert R, van Loo G, et al. 2016. NKT sublineage specification and survival requires the ubiquitin-modifying enzyme TNFAIP3/A20. J Exp Med 213: 1973-1981. doi:10 $.1084 /$ jem.20151065

Duncan CJA, Dinnigan E, Theobald R, Grainger A, Skelton AJ, Hussain R, Willet JDP, Swan DJ, Coxhead J, Thomas MF, et al. 2018. Early-onset autoimmune disease due to a heterozygous loss-of-function mutation in TNFAIP3 (A20). Ann Rheum Dis 77: 783-786. doi:10.1136/annr heumdis-2016-210944

Duong BH, Onizawa M, Oses-Prieto JA, Advincula R, Burlingame A, Malynn BA, Ma A. 2015. A20 restricts ubiquitination of pro-interleukin- $1 \beta$ protein complexes and suppresses NLRP3 inflammasome activity. Immunity 42: 55-67. doi:10.1016/j.immuni.2014.12.031

Duwel M, Welteke V, Oeckinghaus A, Baens M, Kloo B, Ferch U, Darnay BG, Ruland J, Marynen P, Krappmann D. 2009. A20 negatively regulates $T$ cell receptor signaling to NF- $\kappa \mathrm{B}$ by cleaving Malt1 ubiquitin chains. J Immunol 182: 7718-7728. doi:10.4049/jimmunol.0803313

Fischer JC, Otten V, Kober M, Drees C, Rosenbaum M, Schmickl M, Heidegger S, Beyaert R, van Loo G, Li XC, et al. 2017. A20 restrains thymic regulatory $\mathrm{T}$ cell development. J Immunol 199: 2356-2365. doi:10.4049/jimmu nol.1602102

Fujita N, Morita E, Itoh T, Tanaka A, Nakaoka M, Osada Y, Umemoto T, Saitoh T, Nakatogawa H, Kobayashi S, et al. 2013. Recruitment of the autophagic machinery to endosomes during infection is mediated by ubiquitin. J Cell Biol 203: 115-128. doi:10.1083/jcb.201304188

Fukaya M, Brorsson CA, Meyerovich K, Catrysse L, Delaroche D, Vanzela EC, Ortis F, Beyaert R, Nielsen LB, Andersen ML, et al. 2016. A20 inhibits $\beta$-cell apoptosis 
by multiple mechanisms and Predicts residual $\beta$-cell function in type 1 diabetes. Mol Endocrinol 30: 48-61. doi:10.1210/me.2015-1176

Gantier MP, Stunden HJ, McCoy CE, Behlke MA, Wang D, Kaparakis-Liaskos M, Sarvestani ST, Yang YH, Xu D, Corr SC, et al. 2012. A miR-19 regulon that controls NF-кB signaling. Nucleic Acids Res 40: 8048-8058. doi:10.1093/nar/gks521

Garcia-Carbonell R, Wong J, Kim JY, Close LA, Boland BS, Wong TL, Harris PA, Ho SB, Das S, Ernst PB, et al. 2018. Elevated A20 promotes TNF-induced and RIPK1-dependent intestinal epithelial cell death. Proc Natl Acad Sci 115: E9192-E9200. doi:10.1073/pnas.1810584115

Giordano M, Roncagalli R, Bourdely P, Chasson L, Buferne M, Yamasaki S, Beyaert R, van Loo G, Auphan-Anezin N, Schmitt-Verhulst AM, et al. 2014. The tumor necrosis factor $\alpha$-induced protein 3 (TNFAIP3, A20) imposes a brake on antitumor activity of CD8 T cells. Proc Natl Acad Sci 111: 11115-11120. doi:10.1073/pnas.1406259111

Graham RR, Cotsapas C, Davies L, Hackett R, Lessard CJ, Leon JM, Burtt NP, Guiducci C, Parkin M, Gates C, et al. 2008. Genetic variants near TNFAIP3 on 6q23 are associated with systemic lupus erythematosus. Nat Genet 40: 1059-1061. doi:10.1038/ng.200

Guo Q, Dong H, Liu X, Wang C, Liu N, Zhang J, Li B, Cao W, Ding T, Yang Z, et al. 2009. A20 is overexpressed in glioma cells and may serve as a potential therapeutic target. Exp Opin Ther Targets 13: 733-741. doi:10.1517/ 14728220903045018

Haas TL, Emmerich CH, Gerlach B, Schmukle AC, Cordier SM, Rieser E, Feltham R, Vince J, Warnken U, Wenger T, et al. 2009. Recruitment of the linear ubiquitin chain assembly complex stabilizes the TNF-R1 signaling complex and is required for TNF-mediated gene induction. $\mathrm{Mol}$ Cell 36: 831-844. doi:10.1016/j.molcel.2009.10.013

Hammer GE, Turer EE, Taylor KE, Fang CJ, Advincula R, Oshima S, Barrera J, Huang EJ, Hou B, Malynn BA, et al. 2011. Expression of A20 by dendritic cells preserves immune homeostasis and prevents colitis and spondyloarthritis. Nat Immunol 12: 1184-1193. doi:10.1038/ni.2135

Hampe J, Franke A, Rosenstiel P, Till A, Teuber M, Huse K, Albrecht M, Mayr G, De La Vega FM, Briggs J, et al. 2007. A genome-wide association scan of nonsynonymous SNPs identifies a susceptibility variant for Crohn disease in ATG16L1. Nat Genet 39: 207-211. doi:10.1038/ng1954

He KL, Ting AT. 2002. A20 inhibits tumor necrosis factor (TNF) $\alpha$-induced apoptosis by disrupting recruitment of TRADD and RIP to the TNF receptor 1 complex in Jurkat T cells. Mol Cell Biol 22: 6034-6045. doi:10.1128/MCB.22 $.17 .6034-6045.2002$

Heger K, Fierens K, Vahl JC, Aszodi A, Peschke K, Schenten D, Hammad H, Beyaert R, Saur D, van Loo G, et al. 2014. A20-deficient mast cells exacerbate inflammatory responses in vivo. PLoS Biol 12: e1001762. doi:10.1371/jour nal.pbio.1001762

Heyninck K, Denecker G, De Valck D, Fiers W, Beyaert R. 1999. Inhibition of tumor necrosis factor-induced necrotic cell death by the zinc finger protein A20. Anticancer Res 19: 2863-2868. doi:10.1016/0014-5793(96)00283-9

Hitotsumatsu O, Ahmad RC, Tavares R, Wang M, Philpott D, Turer EE, Lee BL, Shiffin N, Advincula R, Malynn BA, et al. 2008. The ubiquitin-editing enzyme A20 restricts nucleotide-binding oligomerization domain containing 2-triggered signals. Immunity 28: 381-390. doi:10.1016/ j.immuni.2008.02.002

Hjelmeland AB, Wu Q, Wickman S, Eyler C, Heddleston J, Shi Q, Lathia JD, Macswords J, Lee J, McLendon RE, et al. 2010. Targeting A20 decreases glioma stem cell survival and tumor growth. PLoS Biol 8: e1000319. doi:10.1371/ journal.pbio.1000319

Honma K, Tsuzuki S, Nakagawa M, Tagawa H, Nakamura S, Morishima Y, Seto M. 2009. TNFAIP3/A20 functions as a novel tumor suppressor gene in several subtypes of nonHodgkin lymphomas. Blood 114: 2467-2475. doi:10 $.1182 /$ blood-2008-12-194852

Hovelmeyer N, Reissig S, Xuan NT, Adams-Quack P, Lukas D, Nikolaev A, Schlüter D, Waisman A. 2011. A20 deficiency in B cells enhances B-cell proliferation and results in the development of autoantibodies. Eur J Immunol 41: 595-601. doi:10.1002/eji.201041313

Hrdinka M, Gyrd-Hansen M. 2017. The Met1-linked ubiquitin machinery: Emerging themes of (de)regulation. Mol Cell 68: 265-280. doi:10.1016/j.molcel.2017.09.001

Hsu AC, Dua K, Starkey MR, Haw TJ, Nair PM, Nichol K, Zammit N, Grey ST, Baines KJ, Foster PS, et al. 2017. MicroRNA-125a and -b inhibit A20 and MAVS to promote inflammation and impair antiviral response in COPD. JCI Insight 2: e90443. doi:10.1172/jci.insight .90443

Hutti JE, Turk BE, Asara JM, Ma A, Cantley LC, Abbott DW. 2007. ІкB kinase $\beta$ phosphorylates the K63 deubiquitinase A20 to cause feedback inhibition of the NF- $\mathrm{BB}$ pathway. Mol Cell Biol 27: 7451-7461. doi:10.1128/MCB .01101-07

Iha H, Peloponese JM, Verstrepen L, Zapart G, Ikeda F, Smith CD, Starost MF, Yedavalli V, Heyninck K, Dikic I, et al. 2008. Inflammatory cardiac valvulitis in TAX1BP1-deficient mice through selective NF- $\mathrm{\kappa B}$ activation. EMBO J 27: 629-641. doi:10.1038/emboj.2008.5

Ikeda F, Deribe YL, Skånland SS, Stieglitz B, Grabbe C, Franz-Wachtel M, van Wijk SJ, Goswami P, Nagy V, Terzic J, et al. 2011. SHARPIN forms a linear ubiquitin ligase complex regulating NF- $\mathrm{KB}$ activity and apoptosis. Nature 471: 637-641. doi:10.1038/nature09814

Iwai K, Tokunaga F. 2009. Linear polyubiquitination: A new

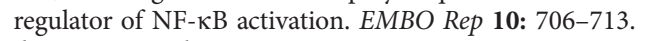
doi:10.1038/embor.2009.144

Jin Z, Li Y, Pitti R, Lawrence D, Pham VC, Lill JR, Ashkenazi A. 2009. Cullin3-based polyubiquitination and p62dependent aggregation of caspase-8 mediate extrinsic apoptosis signaling. Cell 137: 721-735. doi:10.1016/j.cell .2009 .03 .015

Jostins L, Ripke S, Weersma RK, Duerr RH, McGovern DP, Hui KY, Lee JC, Schumm LP, Sharma Y, Anderson CA, et al. 2012. Host-microbe interactions have shaped the genetic architecture of inflammatory bowel disease. Nature 491: 119-124. doi:10.1038/nature11582

Kadowaki T, Ohnishi H, Kawamoto N, Hori T, Nishimura K, Kobayashi C, Shigemura T, Ogata S, Inoue Y, Kawai T, et al. 2018. Haploinsufficiency of A20 causes autoinflammatory and autoimmune disorders. J Allergy Clin Immunol 141: 1485-1488.e11. doi:10.1016/j.jaci.2017.10.039

Kato M, Sanada M, Kato I, Sato Y, Takita J, Takeuchi K, Niwa A, Chen Y, Nakazaki K, Nomoto J, et al. 2009. Frequent 
inactivation of A20 in B-cell lymphomas. Nature 459: 712-716. doi:10.1038/nature07969

Kattah MG, Shao L, Rosli YY, Shimizu H, Whang MI, Advincula $\mathrm{R}$, Achacoso P, Shah S, Duong BH, Onizawa M, et al. 2018. A20 and ABIN-1 synergistically preserve intestinal epithelial cell survival. J Exp Med 215: 1839-1852. doi:10.1084/jem.20180198

Kim SW, Ramasamy K, Bouamar H, Lin AP, Jiang D, Aguiar RC. 2012. MicroRNAs miR-125a and miR-125b constitutively activate the NF- $\mathrm{KB}$ pathway by targeting the tumor necrosis factor $\alpha$-induced protein 3 (TNFAIP3, A20). Proc Natl Acad Sci 109: 7865-7870. doi:10.1073/ pnas. 1200081109

Kolodziej LE, Lodolce JP, Chang JE, Schneider JR, Grimm WA, Bartulis SJ, Zhu X, Messer JS, Murphy SF, Reddy N et al. 2011. TNFAIP3 maintains intestinal barrier function and supports epithelial cell tight junctions. PLoS ONE 6: e26352. doi:10.1371/journal.pone.0026352

Komander D, Barford D. 2008. Structure of the A20 OTU domain and mechanistic insights into deubiquitination. Biochem J 409: 77-85. doi:10.1042/BJ20071399

Kondylis V, Kumari S, Vlantis K, Pasparakis M. 2017. The interplay of IKK, NF- $\mathrm{KB}$ and RIPK1 signaling in the regulation of cell death, tissue homeostasis and inflammation. Immunol Rev 277: 113-127. doi:10.1111/imr.12550

Kool M, van Loo G, Waelput W, De Prijck S, Muskens F, Sze $M$, van Praet J, Branco-Madeira F, Janssens S, Reizis B, et al. 2011. The ubiquitin-editing protein A20 prevents dendritic cell activation, recognition of apoptotic cells, and systemic autoimmunity. Immunity 35: 82-96. doi:10 .1016/j.immuni.2011.05.013

Krikos A, Laherty CD, Dixit VM. 1992. Transcriptional activation of the tumor necrosis factor $\alpha$-inducible zinc finger protein, A20, is mediated by kappa B elements. J Biol Chem 267: 17971-17976.

Kulathu Y, Garcia FJ, Mevissen TE, Busch M, Arnaudo N, Carroll KS, Barford D, Komander D. 2013. Regulation of A20 and other OTU deubiquitinases by reversible oxidation. Nat Commun 4: 1569. doi:10.1038/ncomms2567

Kumar M, Sahu SK, Kumar R, Subuddhi A, Maji RK, Jana K, Gupta P, Raffetseder J, Lerm M, Ghosh Z, et al. 2015. MicroRNA let-7 modulates the immune response to $M y$ cobacterium tuberculosis infection via control of A20, an inhibitor of the NF- $\mathrm{\kappa B}$ pathway. Cell Host Microbe 17: 345-356. doi:10.1016/j.chom.2015.01.007

Langsch S, Baumgartner U, Haemmig S, Schlup C, Schäfer SC, Berezowska S, Rieger G, Dorn P, Tschan MP, Vassella E. 2016. miR-29b mediates NF- $\kappa B$ signaling in KRASinduced non-small cell lung cancers. Cancer Res 76: 4160-4169. doi:10.1158/0008-5472.CAN-15-2580

Lawless D, Pathak S, Scambler TE, Ouboussad L, Anwar R, Savic S. 2018. A case of adult-onset Still's disease caused by a novel splicing mutation in TNFAIP3 successfully treated with tocilizumab. Front Immunol 9: 1527. doi:10 $.3389 /$ fimmu.2018.01527

Lee EG, Boone DL, Chai S, Libby SL, Chien M, Lodolce JP, $\mathrm{Ma}$ A. 2000. Failure to regulate TNF-induced NF- $\mathrm{KB}$ and cell death responses in A20-deficient mice. Science 289: 2350-2354. doi:10.1126/science.289.5488.2350

Lee JG, Baek K, Soetandyo N, Ye Y. 2013. Reversible inactivation of deubiquitinases by reactive oxygen species in vitro and in cells. Nat Commun 4: 1568. doi:10.1038/ ncomms 2532

Lee JH, Jung SM, Yang KM, Bae E, Ahn SG, Park JS, Seo D, Kim M, Ha J, Lee J, et al. 2017. A20 promotes metastasis of aggressive basal-like breast cancers through multi-monoubiquitylation of Snail1. Nat Cell Biol 19: 1260-1273. doi:10.1038/ncb3609

Lin SC, Chung JY, Lamothe B, Rajashankar K, Lu M, Lo YC, Lam AY, Darnay BG, Wu H. 2008. Molecular basis for the unique deubiquitinating activity of the NF- $\mathrm{\kappa B}$ inhibitor A20. J Mol Biol 376: 526-540. doi:10.1016/j.jmb.2007.11 .092

Lippens S, Lefebvre S, Gilbert B, Sze M, Devos M, Verhelst K, Vereecke L, McGuire C, Guerin C, Vandenabeele P, et al. 2011. Keratinocyte-specific ablation of the NF- $\kappa B$ regulatory protein A20 (TNFAIP3) reveals a role in the control of epidermal homeostasis. Cell Death Differ 18: 1845 1853. doi:10.1038/cdd.2011.55

Liuwantara D, Elliot M, Smith MW, Yam AO, Walters SN, Marino E, McShea A, Grey ST. 2006. Nuclear factor- $\kappa \mathrm{B}$ regulates $\beta$-cell death: A critical role for A20 in $\beta$-cell protection. Diabetes 55: 2491-2501. doi:10.2337/db060142

Lodolce JP, Kolodziej LE, Rhee L, Kariuki SN, Franek BS, McGreal NM, Logsdon MF, Bartulis SJ, Perera MA, Ellis NA, et al. 2010. African-derived genetic polymorphisms in TNFAIP3 mediate risk for autoimmunity. J Immunol 184: 7001-7009. doi:10.4049/jimmunol.1000324

Lork M, Verhelst K, Beyaert R. 2017. CYLD, A20 and OTULIN deubiquitinases in NF- $\mathrm{KB}$ signaling and cell death: So similar, yet so different. Cell Death Differ 24: 1172-1183. doi:10.1038/cdd.2017.46

Lu TT, Onizawa M, Hammer GE, Turer EE, Yin Q, Damko E, Agelidis A, Shifrin N, Advincula R, Barrera J, et al. 2013. Dimerization and ubiquitin mediated recruitment of A20, a complex deubiquitinating enzyme. Immunity 38: 896-905. doi:10.1016/j.immuni.2013.03.008

Ma A, Malynn BA. 2012. A20: linking a complex regulator of ubiquitylation to immunity and human disease. Nat Rev Immunol 12: 774-785. doi:10.1038/nri3313

Maelfait J, Roose K, Bogaert P, Sze M, Saelens X, Pasparakis M, Carpentier I, van Loo G, Beyaert R. 2012. A20 (Tnfaip3) deficiency in myeloid cells protects against influenza A virus infection. PLoS Pathog 8: e1002570. doi:10 .1371/journal.ppat.1002570

Maelfait J, Roose K, Vereecke L, McGuire C, Sze M, Schuijs MJ, Willart M, Ibanez LI, Hammad H, Lambrecht BN, et al. 2016. A20 deficiency in lung epithelial cells protects against influenza A virus infection. PLoS Pathog 12: e1005410. doi:10.1371/journal.ppat.1005410

Matmati M, Jacques P, Maelfait J, Verheugen E, Kool M, Sze M, Geboes L, Louagie E, McGuire C, Vereecke L, et al. 2011. A20 (TNFAIP3) deficiency in myeloid cells triggers erosive polyarthritis resembling rheumatoid arthritis. Nat Genet 43: 908-912. doi:10.1038/ng.874

Mauro C, Pacifico F, Lavorgna A, Mellone S, Iannetti A, Acquaviva R, Formisano S, Vito P, Leonardi A. 2006 ABIN-1 binds to NEMO/IKK $\gamma$ and co-operates with A20 in inhibiting NF-кB. J Biol Chem 281: 1848218488. doi:10.1074/jbc.M601502200

McGuire C, Rahman M, Schwaninger M, Beyaert R, van Loo G. 2013. The ubiquitin editing enzyme A20 (TNFAIP3) is 
upregulated during permanent middle cerebral artery occlusion but does not influence disease outcome. Cell Death Dis 4: e531. doi:10.1038/cddis.2013.55

Musone SL, Taylor KE, Lu TT, Nititham J, Ferreira RC, Ortmann W, Shifrin N, Petri MA, Kamboh MI, Manzi S, et al. 2008. Multiple polymorphisms in the TNFAIP3 region are independently associated with systemic lupus erythematosus. Nat Genet 40: 1062-1064. doi:10.1038/ng .202

Nakagawa MM, Thummar K, Mandelbaum J, Pasqualucci L, Rathinam CV. 2015. Lack of the ubiquitin-editing enzyme A20 results in loss of hematopoietic stem cell quiescence. $J$ Exp Med 212: 203-216. doi:10.1084/jem.20132544

Newton K, Dugger DL, Maltzman A, Greve JM, Hedehus M, Martin-McNulty B, Carano RA, Cao TC, van Bruggen N, Bernstein L, et al. 2016. RIPK3 deficiency or catalytically inactive RIPK1 provides greater benefit than MLKL deficiency in mouse models of inflammation and tissue injury. Cell Death Differ 23: 1565-1576. doi:10.1038/cdd.2016 .46

Novak U, Rinaldi A, Kwee I, Nandula SV, Rancoita PM, Compagno M, Cerri M, Rossi D, Murty VV, Zucca E, et al. 2009. The NF- $\kappa B$ negative regulator TNFAIP3 (A20) is inactivated by somatic mutations and genomic deletions in marginal zone lymphomas. Blood 113: 4918-4921. doi:10.1182/blood-2008-08-174110

Ohnishi H, Kawamoto N, Seishima M, Ohara O, Fukao T. 2017. A Japanese family case with juvenile onset Behçet's disease caused by TNFAIP3 mutation. Allergol Int 66: 146-148. doi:10.1016/j.alit.2016.06.006

Okosun J, Bödör C, Wang J, Araf S, Yang CY, Pan C, Boller S, Cittaro D, Bozek M, Iqbal S, et al. 2014. Integrated genomic analysis identifies recurrent mutations and evolution patterns driving the initiation and progression of follicular lymphoma. Nat Genet 46: 176-181. doi:10.1038/ng .2856

Onizawa M, Oshima S, Schulze-Topphoff U, Oses-Prieto JA, $\mathrm{Lu}$ T, Tavares R, Prodhomme T, Duong B, Whang MI, Advincula R, et al. 2015. The ubiquitin-modifying enzyme A20 restricts ubiquitination of the kinase RIPK3 and protects cells from necroptosis. Nat Immunol 16: 618-627. doi:10.1038/ni.3172

Opipari AW Jr, Boguski MS, Dixit VM. 1990. The A20 cDNA induced by tumor necrosis factor $\alpha$ encodes a novel type of zinc finger protein. J Biol Chem 265: 14705-14708.

Pasparakis M, Vandenabeele P. 2015. Necroptosis and its role in inflammation. Nature 517: 311-320. doi:10 $.1038 /$ nature 14191

Patel VI, Daniel S, Longo CR, Shrikhande GV, Scali ST, Czismadia E, Groft CM, Shukri T, Motley-Dore C, Ramsey HE, et al. 2006. A20, a modulator of smooth muscle cell proliferation and apoptosis, prevents and induces regression of neointimal hyperplasia. FASEB J 20: 14181430. doi:10.1096/fj.05-4981com

Peltzer N, Rieser E, Taraborrelli L, Draber P, Darding M, Pernaute B, Shimizu Y, Sarr A, Draberova H, Montinaro A, et al. 2014. HOIP deficiency causes embryonic lethality by aberrant TNFR1-mediated endothelial cell death. Cell Rep 9: 153-165. doi:10.1016/j.celrep.2014.08.066

Polykratis A, Martens A, Eren RO, Shirasaki Y, Yamagishi M, Yamaguchi Y, Uemura S, Miura M, Holzmann B, Kollias
G, et al. 2019. A20 prevents inflammasome-dependent arthritis by inhibiting macrophage necroptosis through its ZnF7 ubiquitin-binding domain. Nat Cell Biol 21: 731-742. doi:10.1038/s41556-019-0324-3

Ramsey HE, Da Silva CG, Longo CR, Csizmadia E, Studer P, Patel VI, Damrauer SM, Siracuse JJ, Daniel S, Ferran C. 2009. A20 protects mice from lethal liver ischemia/reperfusion injury by increasing peroxisome proliferator-activated receptor- $\alpha$ expression. Liver Transpl 15: 16131621. doi:10.1002/lt.21879

Renner F, Schmitz ML. 2009. Autoregulatory feedback loops terminating the NF- $\mathrm{\kappa B}$ response. Trends Biochem Sci 34: 128-135. doi:10.1016/j.tibs.2008.12.003

Rhee L, Murphy SF, Kolodziej LE, Grimm WA, Weber CR, Lodolce JP, Chang JE, Bartulis SJ, Messer JS, Schneider JR, et al. 2012. Expression of TNFAIP3 in intestinal epithelial cells protects from DSS- but not TNBS-induced colitis. Am J Physiol Gastrointest Liver Physiol 303: G220-G227. doi:10.1152/ajpgi.00077.2012

Rioux JD, Xavier RJ, Taylor KD, Silverberg MS, Goyette P, Huett A, Green T, Kuballa P, Barmada MM, Datta LW, et al. 2007. Genome-wide association study identifies new susceptibility loci for Crohn disease and implicates autophagy in disease pathogenesis. Nat Genet 39: 596-604. doi:10.1038/ng2032

Rodriguez MS, Egana I, Lopitz-Otsoa F, Aillet F, Lopez-Mato MP, Dorronsoro A, Lobato-Gil S, Sutherland JD, Barrio R, Trigueros C, et al. 2014. The RING ubiquitin E3 RNF114 interacts with A20 and modulates NF- $\mathrm{KB}$ activity and T-cell activation. Cell Death Dis 5: e1399. doi:10 $.1038 /$ cddis.2014.366

Schmitz R, Hansmann ML, Bohle V, Martin-Subero JI, Hartmann S, Mechtersheimer G, Klapper W, Vater I, Giefing M, Gesk S, et al. 2009. TNFAIP3 (A20) is a tumor suppressor gene in Hodgkin lymphoma and primary mediastinal B cell lymphoma. J Exp Med 206: 981-989. doi:10 $.1084 /$ jem.20090528

Schuijs MJ, Willart MA, Vergote K, Gras D, Deswarte K, Ege MJ, Madeira FB, Beyaert R, van Loo G, Bracher F, et al. 2015. Farm dust and endotoxin protect against allergy through A20 induction in lung epithelial cells. Science 349: 1106-1110. doi:10.1126/science.aac6623

Shembade N, Harhaj NS, Liebl DJ, Harhaj EW. 2007. Essential role for TAX1BP1 in the termination of TNF- $\alpha$-, IL-1and LPS-mediated NF- $\kappa B$ and JNK signaling. $E M B O J$ 26: 3910-3922. doi:10.1038/sj.emboj.7601823

Shembade N, Harhaj NS, Parvatiyar K, Copeland NG, Jenkins NA, Matesic LE, Harhaj EW. 2008. The E3 ligase Itch negatively regulates inflammatory signaling pathways by controlling the function of the ubiquitin-editing enzyme A20. Nat Immunol 9: 254-262. doi:10.1038/ni1563

Shembade N, Parvatiyar K, Harhaj NS, Harhaj EW. 2009. The ubiquitin-editing enzyme A20 requires RNF11 to downregulate NF- $\mathrm{\kappa B}$ signalling. $Е M B O J$ 28: 513-522. doi:10.1038/emboj.2008.285

Shembade N, Ma A, Harhaj EW. 2010. Inhibition of NF- $\kappa B$ signaling by A20 through disruption of ubiquitin enzyme complexes. Science 327: 1135-1139. doi:10.1126/science .1182364

Shigemura T, Kaneko N, Kobayashi N, Kobayashi K, Takeuchi Y, Nakano N, Masumoto J, Agematsu K. 2016. Novel heterozygous C243Y A20/TNFAIP3 gene mutation is re- 
sponsible for chronic inflammation in autosomal-dominant Behçet's disease. RMD Open 2: e000223. doi:10 .1136/rmdopen-2015-000223

Shrikhande GV, Scali ST, da Silva CG, Damrauer SM, Csizmadia E, Putheti P, Matthey M, Arjoon R, Patel R, Siracuse JJ, et al. 2010. O-glycosylation regulates ubiquitination and degradation of the anti-inflammatory protein A20 to accelerate atherosclerosis in diabetic ApoE-null mice. PLoS ONE 5: e14240. doi:10.1371/journal.pone .0014240

Skaug B, Chen J, Du F, He J, Ma A, Chen ZJ. 2011. Direct, noncatalytic mechanism of IKK inhibition by A20. Mol Cell 44: 559-571. doi:10.1016/j.molcel.2011.09.015

Slowicka K, Serramito-Gómez I, Boada Romero E, Martens A, Sze M, Petta I, Vikkula HK, dR R, Parthoens E, Lippens S, et al. 2019. Physical and functional interaction between A20 and ATG16L1-WD40 domain in the control of intestinal homeostasis. Nat Commun 10: 1834. doi:10.1038/ s41467-019-09667-z

Sokhi UK, Liber MP, Frye L, Park S, Kang K, Pannellini T, Zhao B, Norinsky R, Ivashkiv LB, Gong S. 2018. Dissection and function of autoimmunity-associated TNFAIP3 (A20) gene enhancers in humanized mouse models. Nat Commun 9: 658. doi:10.1038/s41467-018-03081-7

Takagi M, Ogata S, Ueno H, Yoshida K, Yeh T, Hoshino A, Piao J, Yamashita M, Nanya M, Okano T, et al. 2017. Haploinsufficiency of TNFAIP3 (A20) by germline mutation is involved in autoimmune lymphoproliferative syndrome. J Allergy Clin Immunol 139: 1914-1922. doi:10.1016/j.jaci.2016.09.038

Tavares RM, Turer EE, Liu CL, Advincula R, Scapini P, Rhee L, Barrera J, Lowell CA, Utz PJ, Malynn BA, et al. 2010. The ubiquitin modifying enzyme A20 restricts B cell survival and prevents autoimmunity. Immunity 33: 181-191. doi:10.1016/j.immuni.2010.07.017

Tewari M, Wolf FW, Seldin MF, O’Shea KS, Dixit VM, Turka LA. 1995. Lymphoid expression and regulation of A20, an inhibitor of programmed cell death. J Immunol 154: 1699-1706.

Ting AT, Bertrand MJM. 2016. More to life than NF- $\mathrm{\kappa B}$ in TNFR1 signaling. Trends Immunol 37: 535-545. doi:10 .1016/j.it.2016.06.002

Tiruppathi C, Soni D, Wang DM, Xue J, Singh V, Thippegowda PB, Cheppudira BP, Mishra RK, Debroy A, Qian Z, et al. 2014. The transcription factor DREAM represses the deubiquitinase A20 and mediates inflammation. Nat Immunol 15: 239-247. doi:10.1038/ni.2823

Tokunaga F, Nishimasu H, Ishitani R, Goto E, Noguchi T, Mio K, Kamei K, Ma A, Iwai K, Nureki O. 2012. Specific recognition of linear polyubiquitin by A20 zinc finger 7 is involved in NF- $\mathrm{\kappa B}$ regulation. $E M B O J$ 31: 3856-3870. doi:10.1038/emboj.2012.241

Vande Walle L, Van Opdenbosch N, Jacques P, Fossoul A, Verheugen E, Vogel P, Beyaert R, Elewaut D, Kanneganti TD, van Loo G, et al. 2014. Negative regulation of the NLRP3 inflammasome by A20 protects against arthritis. Nature 512: 69-73. doi:10.1038/nature 13322

Vereecke L, Sze M, McGuire C, Rogiers B, Chu Y, Schmidt-Supprian M, Pasparakis M, Beyaert R, van Loo G. 2010. Enterocyte-specific A20 deficiency sensitizes to tumor necrosis factor-induced toxicity and experimental colitis. J Exp Med 207: 1513-1523. doi:10.1084/jem .20092474

Vereecke L, Vieira-Silva S, Billiet T, van Es JH, McGuire C, Slowicka K, Sze M, van den Born M, De Hertogh G, Clevers H, et al. 2014. A20 controls intestinal homeostasis through cell-specific activities. Nat Commun 5: 5103. doi:10.1038/ncomms6103

Verhelst K, Carpentier I, Beyaert R. 2011. Regulation of TNF-induced NF- $\kappa \mathrm{B}$ activation by different cytoplasmic ubiquitination events. Cytokine Growth Factor Rev 22: 277-286. doi:10.1016/j.cytogfr.2011.11.002

Verhelst K, Carpentier I, Kreike M, Meloni L, Verstrepen L, Kensche T, Dikic I, Beyaert R. 2012. A20 inhibits LUBACmediated NF- $\kappa B$ activation by binding linear polyubiquitin chains via its zinc finger 7. EMBO J 31: 3845-3855. doi:10.1038/emboj.2012.240

Verstrepen L, Verhelst K, van Loo G, Carpentier I, Ley SC, Beyaert R. 2010. Expression, biological activities and mechanisms of action of A20 (TNFAIP3). Biochem Pharmacol 80: 2009-2020. doi:10.1016/j.bcp.2010.06.044

Voet S, McGuire C, Hagemeyer N, Martens A, Schroeder A, Wieghofer P, Daems C, Staszewski O, Vande Walle L, Jordao MJC, et al. 2018. A20 critically controls microglia activation and inhibits inflammasome-dependent neuroinflammation. Nat Commun 9: 2036. doi:10.1038/ s41467-018-04376-5

Wagner S, Carpentier I, Rogov V, Kreike M, Ikeda F, Löhr F, Wu CJ, Ashwell JD, Dötsch V, Dikic I, et al. 2008. Ubiquitin binding mediates the NF- $\mathrm{KB}$ inhibitory potential of ABIN proteins. Oncogene 27: 3739-3745. doi:10.1038/sj .onc. 1211042

Wang CM, Wang Y, Fan CG, Xu FF, Sun WS, Liu YG, Jia JH. 2011. miR-29c targets TNFAIP3, inhibits cell proliferation and induces apoptosis in hepatitis B virus-related hepatocellular carcinoma. Biochem Biophys Res Commun 411: 586-592. doi:10.1016/j.bbrc.2011.06.191

Wang S, Wen F, Wiley GB, Kinter MT, Gaffney PM. 2013a. An enhancer element harboring variants associated with systemic lupus erythematosus engages the TNFAIP3 promoter to influence A20 expression. PLoS Genet 9: e1003750. doi:10.1371/journal.pgen.1003750

Wang X, Deckert M, Xuan NT, Nishanth G, Just S, Waisman A, Naumann M, Schlüter D. 2013b. Astrocytic A20 ameliorates experimental autoimmune encephalomyelitis by inhibiting NF- $\mathrm{KB}$ - and STAT1-dependent chemokine production in astrocytes. Acta Neuropathol 126: 711724. doi:10.1007/s00401-013-1183-9

Wertz IE, O'Rourke KM, Zhou H, Eby M, Aravind L, Seshagiri S, Wu P, Wiesmann C, Baker R, Boone DL, et al. 2004 De-ubiquitination and ubiquitin ligase domains of A20 downregulate NF- $\mathrm{KB}$ signalling. Nature 430: 694-699. doi:10.1038/nature02794

Wertz IE, Newton K, Seshasayee D, Kusam S, Lam C, Zhang J, Popovych N, Helgason E, Schoeffler A, Jeet S, et al. 2015. Phosphorylation and linear ubiquitin direct A20 inhibition of inflammation. Nature 528: 370-375. doi:10.1038/ nature16165

Won M, Park KA, Byun HS, Sohn KC, Kim YR, Jeon J, Hong JH, Park J, Seok JH, Kim JM, et al. 2010. Novel antiapoptotic mechanism of A20 through targeting ASK1 to suppress TNF-induced JNK activation. Cell Death Differ 17: 1830-1841. doi:10.1038/cdd.2010.47 
A. Martens and G. van Loo

Xia M, Liu J, Wu X, Liu S, Li G, Han C, Song L, Li Z, Wang Q, Wang J, et al. 2013. Histone methyltransferase Ash1l suppresses interleukin-6 production and inflammatory autoimmune diseases by inducing the ubiquitin-editing enzyme A20. Immunity 39: 470-481. doi:10.1016/j.immuni .2013.08.016

Xuan NT, Wang X, Nishanth G, Waisman A, Borucki K, Isermann B, Naumann M, Deckert M, Schlüter D. 2015. A20 expression in dendritic cells protects mice from LPSinduced mortality. Eur J Immunol 45: 818-828. doi:10 .1002/eji.201444795

Yamaguchi N, Yamaguchi N. 2015. The seventh zinc finger motif of A20 is required for the suppression of TNF- $\alpha$ induced apoptosis. FEBS Lett 589: 1369-1375. doi:10 .1016/j.febslet.2015.04.022

Yuk JM, Kim TS, Kim SY, Lee HM, Han J, Dufour CR, Kim JK, Jin HS, Yang CS, Park KS, et al. 2015. Orphan nuclear receptor ERR $\alpha$ controls macrophage metabolic signaling and A20 Expression to negatively regulate TLR-induced inflammation. Immunity 43: 80-91. doi:10.1016/j.immuni.2015.07.003

Zhang Q, Lenardo MJ, Baltimore D. 2017. 30 years of NF$\kappa \mathrm{B}$ : A blossoming of relevance to human pathobiology. Cell 168: 37-57. doi:10.1016/j.cell.2016.12.012

Zhao D, Zhuang N, Ding Y, Kang Y, Shi L. 2016. MiR-221 activates the NF- $\mathrm{KB}$ pathway by targeting A20. Biochem Biophys Res Commun 472: 11-18. doi:10.1016/j.bbrc .2015.11.009

Zhou Q, Wang H, Schwartz DM, Stoffels M, Park YH, Zhang Y, Yang D, Demirkaya E, Takeuchi M, Tsai WL, et al. 2016. Loss-of-function mutations in TNFAIP3 leading to A20 haploinsufficiency cause an early-onset autoinflammatory disease. Nat Genet 48: 67-73. doi:10.1038/ ng.3459 


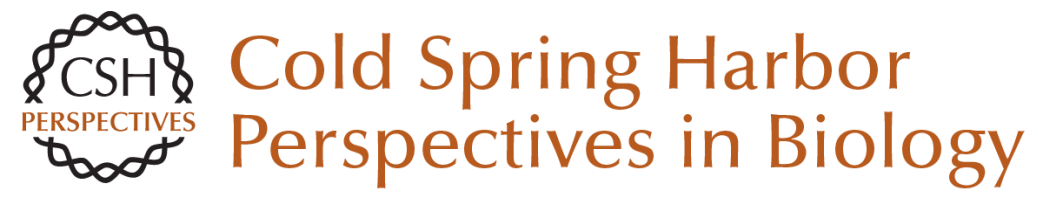

\section{A20 at the Crossroads of Cell Death, Inflammation, and Autoimmunity}

Arne Martens and Geert van Loo

Cold Spring Harb Perspect Biol 2020; doi: 10.1101/cshperspect.a036418 originally published online August 19, 2019

\section{Subject Collection Cell Survival and Cell Death}

Programmed Cell Death in the Evolutionary Race against Bacterial Virulence Factors

Carolyn A. Lacey and Edward A. Miao

The Evolutionary Origins of Programmed Cell

Death Signaling

Kay Hofmann

Regulation of Cell Death and Immunity by XIAP Philipp J. Jost and Domagoj Vucic

Dysregulation of Cell Death in Human Chronic Inflammation

Yue Li, Christoph Klein and Daniel Kotlarz

Cell Death in Plant Immunity

Eugenia Pitsili, Ujjal J. Phukan and Nuria S. Coll

Recent Insights on Inflammasomes, Gasdermin

Pores, and Pyroptosis

Nathalia M. de Vasconcelos and Mohamed Lamkanfi

Phagocyte Responses to Cell Death in Flies Andrew J. Davidson and Will Wood

Mechanism and Regulation of

Gasdermin-Mediated Cell Death

Shiyu Xia, Louis Robert Hollingsworth IV and Hao Wu
Cell Death and Neurodegeneration Benjamin J. Andreone, Martin Larhammar and Joseph W. Lewcock

Death Receptors and Their Ligands in Inflammatory Disease and Cancer Alessandro Annibaldi and Henning Walczak

The Killer Pseudokinase Mixed Lineage Kinase Domain-Like Protein (MLKL) James M. Murphy

Neutrophil Extracellular Traps in Host Defense Sabrina Sofia Burgener and Kate Schroder

Cell-Cycle Cross Talk with Caspases and Their Substrates

Patrick Connolly, Irmina Garcia-Carpio and Andreas Villunger

Cracking the Cell Death Code Carla V. Rothlin and Sourav Ghosh

BAX, BAK, and BOK: A Coming of Age for the BCL-2 Family Effector Proteins Tudor Moldoveanu and Peter E. Czabotar

Multitasking Kinase RIPK1 Regulates Cell Death and Inflammation Kim Newton

For additional articles in this collection, see http://cshperspectives.cshlp.org/cgi/collection/

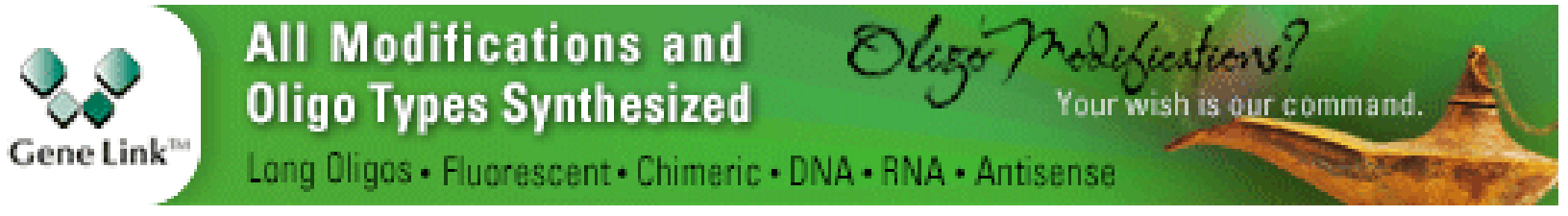


For additional articles in this collection, see http://cshperspectives.cshlp.org/cgi/collection/

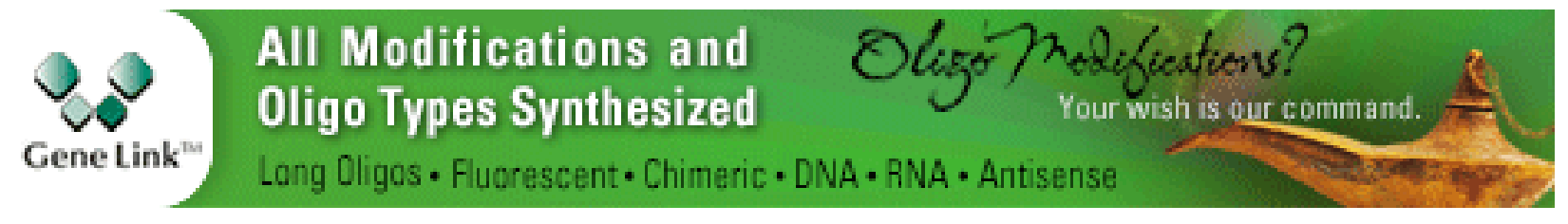

Copyright @ 2020 Cold Spring Harbor Laboratory Press; all rights reserved 